\title{
Kleptoplastidic benthic foraminifera from aphotic habitats: Insights into assimilation of inorganic C, N, and S studied with sub-cellular resolution
}

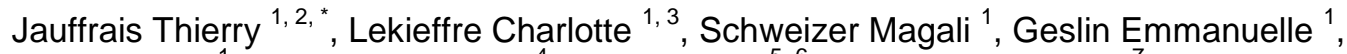 \\ $\begin{array}{r}\text { Metzger Edouard }{ }^{1} \text {, Bernhard Joan M. }{ }^{4} \text {, Jesus Bruno } \\ \text { Meibom Anders }\end{array}{ }^{3,10},{ }_{10}$ Filipsson Helena L. ${ }^{7}$, Maire Olivier ${ }^{8,9}$,
}

${ }^{1}$ UMR CNRS 6112 LPG-BIAF; Université d'Angers; 2 Boulevard Lavoisier, 49045 Angers CEDEX 1, France

2 Ifremer, RBE/LEAD; 101 Promenade Roger Laroque, 98897 Nouméa, New Caledonia

${ }^{3}$ Laboratory for Biological Geochemistry; School of Architecture, Civil and Environmental Engineering (ENAC), Ecole Polytechnique Fédérale de Lausanne (EPFL); 1015 Lausanne ,Switzerland

${ }^{4}$ Woods Hole Oceanographic Institution; Geology \& Geophysics Department; Woods Hole MA ,USA

${ }^{5}$ EA2160, Laboratoire Mer Molécules Santé; Université de Nantes; Nantes, France

${ }^{6}$ BioISI - Biosystems \& Integrative Sciences Institute; Campo Grande University of Lisboa Faculty of

Sciences; Lisboa ,Portugal

7 Department of Geology; Lund University; Sölvegatan 12, SE-223 62 Lund, Sweden

${ }^{8}$ Univ. Bordeaux; EPOC, UMR 5805, F-33400 Talence, France

${ }^{9}$ CNRS, EPOC; UMR 5805, F-33400 Talence, France

${ }^{10}$ Center for Advanced Surface Analysis; Institute of Earth Sciences, University of Lausanne; 1015 Lausanne ,Switzerland

*Corresponding author : Thierry Jauffrais, email address : thierry.jauffrais@ifremer.fr

\begin{abstract}
:
The assimilation of inorganic compounds in foraminiferal metabolism compared to predation or organic matter assimilation is unknown. Here we investigate possible inorganic-compound assimilation in Nonionellina labradorica, a common kleptoplastidic benthic foraminifer from Arctic and North Atlantic sublittoral regions. The objectives were to identify the source of the foraminiferal kleptoplasts, assess their photosynthetic functionality in light and darkness, and investigate inorganic nitrogen and sulfate assimilation. We used DNA barcoding of a $~ 830 \mathrm{bp}$ fragment from the SSU rDNA to identify the kleptoplasts, and correlated transmission electron microscopy and nanometer-scale secondary ion mass spectrometry (TEM-NanoSIMS) isotopic imaging to study 13C-bicarbonate, $15 \mathrm{~N}$-ammonium, and 34S-sulfate uptake. In addition, respiration rate measurements were determined to assess the response of $\mathrm{N}$. labradorica to light. The DNA sequences established that over $80 \%$ of the kleptoplasts belonged to Thalassiosira (with 96-99\% identity), a cosmopolitan planktonic diatom. TEM-NanoSIMS imaging revealed degraded cytoplasm and an absence of $13 \mathrm{C}$ assimilation in foraminifera exposed to light. Oxygen measurements showed higher respiration rates under light than dark conditions, and no $\mathrm{O} 2$ production was detected. These results indicate that the photosynthetic pathways in N. labradorica are not functional. Furthermore, N. labradorica assimilated both $15 \mathrm{~N}$-ammonium and $34 \mathrm{~S}$-sulfate into its cytoplasm, which suggests that foraminifera might have several ammonium or sulfate assimilation
\end{abstract}


pathways, involving either the kleptoplasts or bona fide foraminiferal pathway(s) not yet identified. 


\section{Introduction}

Benthic foraminifera are known to use a wide range of feeding mechanisms and nutritional resources: grazing, passive suspension feeding, uptake of re-suspended organic matter and dissolved organic carbon, parasitism, and predation (Delaca et al., 1981; Cedhagen, 1988, 1994; Moodley et al., 2002; Witte et al., 2003; Nomaki et al., 2008; Dupuy et al., 2010). These heterotrophic mechanisms give them the ability to live in most marine sedimentary environments; from shallow-water estuaries to deep-sea basins. Some species developed further physiological adaptations, such as the capacity to store nitrate and to denitrify (Risgaard-Petersen et al., 2006; Piña-Ochoa et al., 2010b; Piña-Ochoa et al., 2010a; Bernhard et al., 2012b), and/or to host endo- and ectosymbionts (Bernhard et al., 2000; Bernhard, 2003; Bernhard et al., 2006; Bernhard et al., 2010; Schmidt et al., 2016; Bernhard et al., 2018). Among these adaptations, some species have the ability to ingest and maintain intact chloroplasts (kleptoplasts) in their cytosol from days to many months (Correia and Lee, 2002a; Grzymski et al., 2002). This process is called kleptoplasty (Clark et al., 1990) and has been observed in multiple intertidal to deep-sea foraminifera (Lopez, 1979; Lee et al., 1988; Cedhagen, 1991; Bernhard and Bowser, 1999; Correia and Lee, 2000, 2002b, a; Bernhard, 2003; Goldstein et al., 2004; Pillet et al., 2011; Tsuchiya et al., 2015; Goldstein and Richardson, 2018; Jauffrais et al., 2018).

Kleptoplast functionality has been demonstrated and studied mainly in foraminiferal species on intertidal mudflats (Lopez, 1979; Lee et al., 1988; Jauffrais et al., 2016; Cesbron et al., 2017; Jauffrais et al., 2017, Tsuchiya et al., 2018). However, some kleptoplastidic species live in the aphotic zone. For these species knowledge about their biology (Bernhard and Bowser, 1999) and their role in biogeochemical cycles is sparse (Bernhard et al., 2012). These foraminifera are generally tolerant to low-oxygen concentrations (hypoxia / anoxia) and some are known to denitrify (Risgaard-Petersen et al., 2006; Piña-Ochoa et al., 2010b). Bernhard 
and Bowser (1999) and Grzymski et al. (2002) studied kleptoplasts from foraminifera living in aphotic oxygen-depleted to anoxic habitats, and suggested that these kleptoplasts have a role in the assimilation of inorganic nitrogen and sulfate. One plausible hypothesis about these kleptoplasts is that they facilitate the assimilation of inorganic nitrogen via their glutamine synthetase and glutamate 2-oxo-glutarate aminotransferase (GS-GOGAT) enzymatic machinery (Grzymski et al., 2002), in addition to a potential photosynthetic pathway, and a general heterotrophic (non-photosynthetic) pathway, which together might fulfill the organism's requirement for inorganic and organic carbon.

Here we studied the species Nonionellina labradorica (Dawson, 1860) living in total darkness within the sediments in the Gullmar Fjord, Sweden; where ammonium pore water concentrations can varied from 0.7 to $20 \mu \mathrm{M}$ in the first four centimeters of the sediment (Brandsma et al., 2011) and where sulfate concentration is situated around 26-28 mM (Goldberg et al., 2012). We combined ultrastructural analyses, which were executed with a transmission electron microscope (TEM), correlated with nanometer scale secondary ion mass spectrometry (NanoSIMS) imaging (Hoppe et al., 2013; Nuñez et al., 2018) to localize isotopically labeled ${ }^{15} \mathrm{~N},{ }^{13} \mathrm{C}$, and ${ }^{34} \mathrm{~S}$ compounds at a sub-cellular level and to correlate the elemental isotopic composition with ultrastructural features of $N$. labradorica. This TEMNanoSIMS analysis has revealed the fate of isotopically labeled compounds in diverse marine microorganisms (Finzi-Hart et al., 2009; Pernice et al., 2012; Kopp et al., 2013; Kopp et al., 2015a; Raina et al., 2017), including foraminifera (Nomaki et al., 2016; LeKieffre et al., 2017, LeKieffre et al., 2018a). Additionally, microelectrodes were used to determine the oxygen dynamics around N. labradorica as a function of artificial light exposure (Rink et al., 1998; Geslin et al., 2011), in order to link $\mathrm{C}$ and $\mathrm{N}$ assimilation with potential photosynthetic activity. 
In this contribution, we explore the relationships between planktonic diatoms, kleptoplasts, a foraminiferal species, and the biogeochemistry of the fjord. Specifically, we investigate: (1) the phylogenetic identity of $N$. labradorica kleptoplasts; (2) kleptoplast photosynthetic functionality, i.e., oxygen production and inorganic carbon assimilation; and (3) possible inorganic nitrogen and sulfate assimilation by $N$. labradorica.

\section{Results}

\section{Foraminiferal and kleptoplast identifications}

The $N$. labradorica specimens imaged with SEM for further morphological observation and with positive PCR amplifications $(n=4)$ were used for sequencing. The 236 sequences obtained from these specimens were deposited in GenBank (accession numbers in Table SI. $1)$.

The primers $14 \mathrm{~F} 1$ and $\mathrm{J} 2$ are foraminifer specific and target a $\sim 1000 \mathrm{bp}$ region at the $3{ }^{\prime}$ end of the SSU rDNA gene used for foraminiferal barcoding (Pawlowski and Holzmann, 2014). The foraminiferal clones were 98-99 \% identical to sequences deposited in GenBank and identified as $N$. labradorica collected in the Skagerrak, Svalbard and the White Sea (Schweizer et al., 2005; Schweizer et al., 2008; Schweizer et al., 2009; Holzmann and Pawlowski, 2017).

The primers DiatSSUF and DiatSSUR amplify a $\sim 830$ bp region in the middle of the SSU gene and are used to study kleptoplasts (Pillet et al., 2011). Our results show that these primers, first designed as bacillariophyte-specific primers (Pillet et al., 2011), amplify in fact 18S rDNA from a broad range of eukaryotes; i.e. not only from the stramenopiles or SAR supergroup, but also from opisthokonts, such as the rotifers and fungi, which represent $18 \%$ of the clones sequenced in our study (Fig. 1). The 117 sequenced clones of eukaryotic 18S 
rDNA were separated into four groups: a first group with 94 sequences (up to $2.5 \%$ divergence), a second group with 15 sequences (up to $0.6 \%$ divergence), a third group with six sequences (up to $2.7 \%$ divergence), and a fourth group with two sequences (up to $0.7 \%$ divergence). BLAST identified the first group as belonging to the diatom genus Thalassiosira (99\% identity), the second group to bdelloid rotifers (99\% identity), the third group to fungi related to Cladosporium sp. (95-99\% identity), and the fourth group to euglenids (90\% identity with Rhynchopus and Diplonema). The 94 sequences of Thalassiosira were then aligned with other $18 \mathrm{~S}$ diatom sequences from GenBank to obtain a phylogenetic tree (Fig. 2). The diatomaceous sequences appear as three main groups, which can be considered as different species (Thalassiosira sp. 1, Thalassiosira sp. 2 and Thalassiosira sp. 3), within the clade including all Thalassiosirales. The groups have a very good branch support estimation, with 0.95 for Thalassiosira sp. 1, 0.87 for Thalassiosira sp. 2 and 0.85 for Thalassiosira sp. 3 . When comparing our clones with partial 18S sequences of various Thalassiosira species taken from GenBank (Fig. 2, Table SI. 1), Thalassiosira sp. 1 does not group with any published sequence, Thalassiosira sp. 2 groups with Thalassiosira nordenskioeldii and Thalassiosira sp. 3 groups with Thalassiosira hendeyi. Four other sequences were different from these three clades (Table SI. 1) and were only identified at the genus level (Thalassiosira spp.).

The primers PLA491F and OXY1313R used to amplify a 800 bp fragment of the 16S rDNA of kleptoplasts were designed to detect a broad range of chloroplasts, including plants and green algae (Pillet et al., 2011). The 116 sequenced clones of $16 \mathrm{~S}$ rDNA all belonged to diatomaceous chloroplasts (Fig. 1, Table SI. 1); 98 were 96-99\% identical to Thalassiosira chloroplasts with BLAST, whereas 18 other clones were 94-99\% identical to chloroplasts of other planktonic diatoms such as Chaetoceros, Odontella or Lauderia (Table SI. 1).

\section{Ultrastructural characteristics}


The specimens fixed after $20 \mathrm{~h}$ of incubation under dark or light conditions showed different ultrastructural characteristics (Figs. 3 and 4).

After $20 \mathrm{~h}$ in darkness, the cytoplasm remained intact and was filled with material and vacuoles well delimited by membranes in all specimens ( $\mathrm{n}=5$ each). Most kleptoplasts had intact girdle lamellae, thylakoids, and pyrenoids and were evenly distributed in the foraminifera (Figs. 3B and 4A, C), but some kleptoplasts were also degraded and/or in division (Figs. 3B-D and 4A, C). Intact and numerous lipid droplets were present throughout the foraminiferal cytoplasm (Figs. 3 and 4A, C). Electron-opaque bodies (Fig. 3E, F) and fibrillar vesicles (Fig. 3F) were also distributed in all foraminiferal chambers and the observation of intact mitochondria (Fig. 3G) confirmed that these foraminiferal specimens were alive and healthy at the end of this dark exposure (Nomaki et al., 2016).

After $20 \mathrm{~h}$ of light exposure, the cytoplasm of all $N$. labradorica specimens $(\mathrm{n}=5)$ examined was in a degraded state. Except for lipid droplets and kleptoplasts, all the observed organelles had disrupted membranes and could not be identified (e.g., electron-opaque bodies, mitochondria or fibrillar vesicles, Fig. 4B, D). In addition, in these specimens, all the observed kleptoplasts were degraded (Fig 4B and D) and no intact foraminiferal mitochondria were observed.

The number of kleptoplasts was similar in the two treatments (light vs dark) at the end of the experiment. The area occupied by kleptoplasts in our images was equal to $15 \pm 6 \%$ of the cytoplasm in the dark condition and $11 \pm 3 \%$ of the cytoplasm in the light $(\mathrm{P}$-value $=0.35$, $\mathrm{n}=5$ ). However, kleptoplast appearance was more degraded (P-value $=0.009, \mathrm{n}=5)$ in the light treatment compared to that of the dark, with $63 \pm 16 \%$ of kleptoplasts showing signs of degradation when exposed to light, while only $22 \pm 12 \%$ appeared degraded when maintained in darkness. 


\section{Isotopic labeling}

Following incubation with ${ }^{13} \mathrm{C}$-bicarbonate under both dark and light conditions, no ${ }^{13} \mathrm{C}$ enrichment was detected in any of the specimens examined (Fig. 5B, C and Fig. 6B, C), with maximum ${ }^{13} \mathrm{C}$ 'enrichment' values less than $100 \%$, i.e., indistinguishable from values obtained from similar-sized regions in control specimens. However, specimens incubated in darkness showed clear ${ }^{15} \mathrm{~N}$-enrichments (up to $20000 \%$, which is equivalent to a ${ }^{15} \mathrm{~N} /\left({ }^{15} \mathrm{~N}+{ }^{14} \mathrm{~N}\right)$ ratio of 7.2 at\%) associated with electron-opaque bodies (Figs. 5D, E, F), and ${ }^{34} \mathrm{~S}$-enrichments (up to $7000 \%$, which is equivalent to a ${ }^{34} \mathrm{~S} /\left({ }^{34} \mathrm{~S}+{ }^{32} \mathrm{~S}\right.$ ) ratio of 25.9 at\%) associated with fibrillar vesicles and electron opaque bodies (Figs. 5G, H, I). In contrast, after incubation under light only weak ${ }^{15} \mathrm{~N}$ (up to $600 \%$, or 0.6 at $\%$ ) and ${ }^{34} \mathrm{~S}(2000 \%$, or 11.6 at\%) enrichments were observed in unidentifiable degraded organelles (Figs. 6D, E, F and Figs. 6G, H, I).

\section{Respiration rates}

Microelectrode profile data indicated that the specimens exposed to the different experimental conditions (light/dark) showed large differences between respiration rates driven by light and time of exposure (Fig. 7). Furthermore, no kleptoplast photosynthetic functionality regarding oxygen production was observed.

Under light exposure, a large increase in respiration rate was observed compared to darkness (Fig. 7). The shift between dark and light respiration rates occurred over only a few minutes. The light and dark respiration rates decrease over time: under light exposure from 4500 to $2000 \mathrm{pmol} \mathrm{O}_{2}$ cell $^{-1} \mathrm{~d}^{-1}$, and under dark exposure from 2400 to $1400 \mathrm{pmol} \mathrm{O}_{2}$ cell $^{-1} \mathrm{~d}^{-1}$ (Fig. 6). Accordingly, the maximum difference between light and dark respiration rate also gradually decreased from 2500 to $1000 \mathrm{pmol} \mathrm{O}_{2}$ cell $^{-1} \mathrm{~d}^{-1}$ over time. 


\section{Discussion}

\section{Molecular identification of kleptoplasts through 18 S and 16S rDNA}

More than $80 \%$ of the $18 \mathrm{~S}$ rDNA clones and the $16 \mathrm{~S}$ rDNA clones belong to Thalassiosira spp., indicating that the benthic $N$. labradorica presumably ingests this planktonic diatom in large amounts (Fig. 1). The $18 \mathrm{~S}$ sequences showed that at least three species of Thalassiosira were identified in N. labradorica (Fig. 2). A closer examination of our sequences compared to the Thalassiosira 18S sequences available from GenBank (Fig. 2) indicates that Thalassiosira sp. 2 may be identified as T. nordenskioeldii, a species living in the Gullmar Fjord (McQuoid, 2005); whereas, Thalassiosira sp. 3, identified as T. hendeyi, is known from the nearby North Sea (Hoppenrath et al., 2007). The only diatom genus identified with $18 \mathrm{~S}$ data was Thalassiosira and 16S sequences indicated a diatom origin. Most of the $16 \mathrm{~S}$ sequences belonged to Thalassiosira chloroplasts, whereas $15.5 \%$ belonged to the chloroplasts of other genera such as Chaetoceros, Odontella and Lauderia, three planktonic diatoms also found in the Gullmar Fjord and the North Sea (McQuoid, 2005). Interestingly, Odontella sp. DNA sequences were already observed in $N$. stella kleptoplasts, a foraminifer often isolated in the Santa Barbara Basin (Grzymski et al., 2002).

The $16 \mathrm{~S}$ sequences are not specific enough to have a taxonomic precision beyond the family or genus (Pillet et al., 2011). These kleptoplasts may belong to diatoms that were digested before the Thalassiosira and their nuclear content would have disappeared whereas the kleptoplasts remained in the foraminifer. Further studies are needed to determine if $N$. labradorica phagocytoses the most abundant diatoms present in the environment or if it is genus/species selective.

The presence of bdelloid rotifer DNA within a single foraminifer (GF366) may indicate that N. labradorica ingests these animals. Although bdelloids live in fresh waters, they can be 
exported to the sea in high numbers via estuaries (Fradkin, 2001). This would not be the first example of a foraminifer feeding on an animal larger than itself (Bowser et al., 1992; Dupuy et al., 2010). The euglenid-like sequences found in GF367 could also be ingested by the foraminifer, whereas the DNA of fungal origin is more difficult to interpret; they may be prey, parasitic or commensal.

\section{Ultrastructural organization and description}

Our results indicate that $N$. labradorica maintains diatom kleptoplasts and that these were densely and evenly distributed in the foraminiferal cytoplasm (Fig. 3). Kleptoplast localization in foraminifera is now known to differ between species (Jauffrais et al., 2018). The distribution pattern of $N$. labradorica kleptoplasts throughout the cytoplasm and chambers in the present study has also been observed in the foraminifera Haynesina germanica and Elphidium oceanense, whereas in other foraminiferal species kleptoplasts are situated close to the foraminiferal cell periphery and/or pore-plate complexes (e.g., $E$. williamsoni, E. selseyense, Planoglabratela opercularis, Jauffrais et al., 2018). Furthermore, the $N$. labradorica kleptoplasts were found intact, in division or showing signs of degradation. This is in agreement with previous TEM observations made on this species (Cedhagen, 1991): the state of degradation could be considered similar to what might be encountered in a diatom bloom sinking in a fjord before becoming phytodetritus. There are two possible explanations to account for the occurrence of dividing chloroplasts. The first explanation is active division of the plastid in the host endoplasm. However, without the diatom nucleus-encoded proteins that constitute the chloroplast-division machinery, kleptoplasts should not be able to divide (Miyagishima, 2011). Nevertheless, diatom nuclear DNA was amplified in the present study thus the foraminiferal host might have enough diatom nucleus-encoded proteins reserved to allow for some division, using freshly ingested diatoms. The second and maybe most 
probable explanation to account for dividing plastids is that $N$. labradorica ingested a diatom cell blocked in its $\mathrm{S}$ or $\mathrm{G} 2$ cell cycle phase due to environmental stresses (e.g. nutrient limitation) often observed in sinking blooms (Vaulot et al., 1987; Brzezinski et al., 1990). The $\mathrm{S}$ and G2 phases in eukaryotic algae are the phases of the cell cycle where chloroplast division occurs (Sumiya et al., 2016).

Empty vacuoles, lipid droplets, and other organelles such as mitochondria, electron-opaque bodies, and fibrillar vesicles were also densely and apparently homogeneously distributed in the endoplasm of the $N$. labradorica (Fig. 3).

Interestingly, after $20 \mathrm{~h}$ of light exposure $\left(90 \mu \mathrm{mol} \mathrm{m} \mathrm{m}^{-2} \mathrm{~s}^{-1}\right)$, the cytoplasm of all examined $N$. labradorica specimens was degraded, with only lipid droplets and kleptoplasts still distinguishable although most of those were in degradation (Fig. 4B, D). Conversely, when $N$. labradorica specimens were maintained in darkness, all ultrastructural features were still clearly visible and recognizable, with organelles exhibiting intact membranes and internal structures (Fig. 4A, C). This light-induced degradation of the foraminiferal ultrastructural features coupled to the respiration rate increase under light clearly indicates that $N$. labradorica is negatively impacted by light. Furthermore, it suggests that $N$. labradorica is unable to manage the oxidative stress produced when exposed to light - ultimately causing the death of the individual.

Finally, it is also important to emphasize that no endobionts or ectobionts were observed in any $N$. labradorica that we observed with TEM. In previous studies, the role of putative symbionts in $\mathrm{N}$ or $\mathrm{S}$ assimilation in other foraminiferal species have been shown or suggested in both coastal (Nomaki et al., 2016) and deep-sea environments (Bernhard et al., 2000; Bernhard, 2003; Bernhard et al., 2006; Bernhard et al., 2010; Bernhard et al., 2012a). Such physiological adaptations (e.g., symbiosis and kleptoplasty) may thus provide more than one mechanism for $\mathrm{N}$ and $\mathrm{S}$ cycling in foraminifera. 


\section{Isotopic labeling}

No ${ }^{13}$ C-enrichment was detected under either light regime (light vs. darkness) in any of the $N$. labradorica specimens sampled at the aphotic $70 \mathrm{~m}$ water depth in this study (Figs. 5 and 6). The kleptoplasts did not assimilate any ${ }^{13} \mathrm{C}$-bicarbonate, thus the Calvin-Benson cycle was certainly not functional in $N$. labradorica kleptoplasts. It is also noteworthy that $F v / F m=0$ in $N$. labradorica, so photosystem II of the kleptoplasts was also not functional (measured by pulse amplitude modulated (PAM) fluorometry as in Jauffrais et al. ( 2016); data not shown). Note that chemical fixation protocols cause loss of soluble compounds and include infiltration of the fixed tissue with resin of normal $\mathrm{C}$-isotopic composition, which dilutes potential ${ }^{13} \mathrm{C}$ enrichment in the sample (Musat et al. 2014; Kopp et al., 2015b; Nomaki et al., 2018).

In intertidal kleptoplastidic foraminiferal species, oxygenic photosynthesis was found to be functional and inorganic carbon assimilation was demonstrated (Lopez, 1979, LeKieffre et al. 2018a). However, below the photic limit, which typically does not exceed $15-20 \mathrm{~m}$ in the Gullmar Fjord during the season we sampled (Erlandsson and Stigebrandt, 2006), it is unlikely that oxygenic photosynthesis would occur. This process involves multiple reactions leading to the transformation of inorganic carbon to organic carbon and all the light driven reactions and Calvin-Benson cycle must be active. However, in kleptoplastidic foraminiferal species from aphotic environments few studies have been conducted to date (Cedhagen, 1991; Grzymski et al., 2002) and only one has investigated photosynthesis functionality. Cedhagen (1991) studied $N$. labradorica photosynthesis using radioactive ${ }^{14} \mathrm{C}$-labeling on individuals collected at two different seasons. Specimens collected at $35 \mathrm{~m}$ depth during winter showed no detectable trace of photosynthesis, whereas specimens collected from the same location during summer produced a ${ }^{14} \mathrm{C}$-signal attributed to photosynthesis $\left(2.1210^{-10} \mathrm{mg} \mathrm{C} \mathrm{cell}^{-1} \mathrm{~h}^{-1}\right)$. 
At that time, the observed difference was attributed to a higher number of kleptoplasts in August than in February. In the present study, N. labradorica was sampled at $70 \mathrm{~m}$ in May and had a greenish-brown coloration with numerous kleptoplasts. However, inorganic carbon uptake and $\mathrm{O}_{2}$ production by photosynthesis were not observed and the photosystem II of these kleptoplasts was not functional. All these data indicate that the kleptoplast photosynthetic pathways in $N$. labradorica cells were not functional in our population.

In the present study, ${ }^{15} \mathrm{~N}$-enrichments after incubation with ${ }^{15} \mathrm{~N}$-ammonium under darkness were concentrated in N. labradorica electron-opaque bodies (Figs. 5D, F, J). This shows that ammonium uptake and assimilation pathways exist in $N$. labradorica (although the pathway is presently not identified) and this pathway(s) is not light driven.

Interestingly, nitrogen assimilation (i.e., nitrite and ammonium) by kleptoplastidic sea slugs (e.g., Elysia viridis) and dinoflagellate/coral symbioses was observed during incubation in either light or dark conditions; higher $\mathrm{N}$ assimilation occurred in specimens exposed to light (Teugels et al., 2008; Kopp et al., 2013; Kopp et al., 2015b). Furthermore, N-assimilation in darkness was also inferred for the kleptoplastidic foraminifera N. stella (Grzymski et al., 2002). Ammonium uptake and assimilation has a central role in metabolic pathways in many photosynthetic organisms. The main route for ammonium assimilation is through the GSGOGAT, where ammonium ions are incorporated into glutamine and glutamate (Lam et al., 1996). The glutamine synthetase (GS) first catalyzes the ammonium incorporation into glutamate using ATP to yield glutamine. The glutamine synthetase is present in both the cytosol (GS1) and in the chloroplasts and plastids (GS2). Then GOGAT, which occurs in three forms using either NADPH, NADH, or reduced ferredoxin (Fd) as electron donor, forms L-glutamate from the conversion of L-glutamine and 2-oxoglutarate (reviewed in Suzuki and Knaff (2005)). The GS metabolic reaction is ATP-dependent, and gene expressions of GS and 
GOGAT are regulated by several factors: light, $\mathrm{C}$ and $\mathrm{N}$ metabolite-levels, and by phytochromes (Sakakibara et al., 1992; Becker et al., 1993; Melo-Oliveira et al., 1996; Oliveira and Coruzzi, 1999; Grossman and Takahashi, 2001). However, working with mutated plants in isotopic labeling experiments, ammonium assimilation occurred via the GS and residual Fd-GOGAT and/or NADH-GOGAT synthase in darkness, but at lower rates than in light (Somerville and Ogren, 1980; Kendall et al., 1986; Magalhães et al., 1990; Häusler et al., 1994; Ferrario-Méry et al., 2000; Aubert et al., 2001; Lancien et al., 2002). This last observation leads us to propose that our observation of ammonium assimilation in darkness via kleptoplasts might take place via the GS-GOGAT pathways (Fig. 8).

An alternative, or secondary, system for ammonium assimilation also exists in mitochondria through the glutamate dehydrogenase (GDH) pathway, which forms glutamate from the reductive amination of 2-oxoglutarate by ammonium (Suzuki and Knaff, 2005). This pathway has been suggested to have a potential role in kleptoplastidic seaslugs (Teugels et al., 2008), and may be active in $N$. labradorica. Indeed, both pathways might be operating in the foraminiferal cell, but such a hypothesis requires further support by determination of the enzymes involved.

Isotopic labeling with ${ }^{34} \mathrm{~S}$-enriched sulfate yielded higher foraminifera cell ${ }^{34} \mathrm{~S}$-enrichments in darkness than in light, and this enrichment was concentrated primarily in two specific organelles: fibrillar vesicles and electron opaque bodies (Figs. 5 and 6). A previous study showed that ${ }^{34} \mathrm{SO}_{4}{ }^{2-}$ were accumulated in a species of benthic foraminifera (Ammonia sp.) in both anoxic and hypoxic conditions (Nomaki et al., 2016). This species had potential symbionts but no kleptoplasts. In the study by Nomaki et al. (2016) it was found that mitochondria, cytosomes (i.e. the cytoplasmic portion of the cell with no obvious organelles), and electron dense bodies (similar organelle to our electron opaque bodies (LeKieffre et al., 
2018b)) were labeled with ${ }^{34} \mathrm{~S}$. But the accumulation was higher in the hypoxic incubation compared to the anoxic incubation, possibly, due to a higher metabolic activity under hypoxia than anoxia (Nomaki et al., 2016). The ${ }^{34}$ S-labeled organelles in Ammonia sp. and $N$. labradorica differed but with one common organelle (i.e., electron opaque bodies). Thus our observations confirm that electron-opaque bodies play a role in sulfate metabolism (Nomaki et al., 2016), as these organelles were labeled in both species. The different accumulation pattern observed between this study and the Nomaki et al. (2016) study may be due to the different incubation durations and/or experimental design and/or species specific Sassimilation pathways. Indeed, Ammonia sp. hosting endobionts and no kleptoplasts was incubated in sediment with ${ }^{34}$ S-sulfate in either anoxia or hypoxia (Nomaki et al., 2016). In contrast, $N$. labradorica (this study) had kleptoplasts but no endobionts, and was cleaned and incubated in ASW spiked in ${ }^{34} \mathrm{~S}$-sulfate. Finally, the ${ }^{34} \mathrm{~S}$-enrichment in fibrillar vesicles supports their supposed role in transport and storage of glycosaminoglycans (a sulfated polysaccharide), which is a major component of organic linings, organic cements and secretion products of foraminifera (Langer, 1992).

Sulfate assimilation in eukaryotic organisms is used for sulfatation of compounds into cysteine (Leustek and Saito, 1999; Saito, 2000). Once $\mathrm{SO}_{4}{ }^{2-}$ enters cells, it is assimilated by ATP sulfurylase to form adenosine 5'-phosphosulfate (APS). In plants and algae the ATP sulfurylase isoforms are located either in plastids or in the cytosol (Lunn et al., 1990). Also, cysteine is synthesized from sulfide and $\mathrm{O}$-acetylserine (OAS) in a reaction catalyzed by Oacetylserine(thiol)lyase (OASTL), which is present also in the cytosol, plastids, and mitochondria (Lunn et al., 1990). These observations on other phyla suggest a potential role of the kleptoplasts in $\mathrm{S}$ assimilation in benthic kleptoplastidic foraminifera. However, this hypothesis of a kleptoplast function in sulfur assimilation was already thought to be unlikely by Grzymski et al (Grzymski et al., 2002) from a photophysiological perspective in the close 
relative Nonionella stella. Furthermore, the fact that electron opaque bodies are labeled with

${ }^{34} \mathrm{~S}$ in both $N$. labradorica (present study) and in Ammonia sp. (Nomaki et al., 2016) supports the hypothesis that foraminifera have a sulfate assimilation system that may not be linked to kleptoplasts.

In conclusion, molecular analyses showed that $N$. labradorica kleptoplasts are derived primarily from planktonic diatoms; four genera of diatoms were identified with Thalassiosira as the most abundant genus. If the results from this study can be extrapolated to other species of kleptoplastidic benthic foraminifera from aphotic habitats, it shows that the photosynthetic metabolism is irrelevant or of very little importance as an energy source for these species. However, even if our study cannot ruled out that kleptoplasts might be used as an energy storage to be slowly digested (within many days) during food impoverished period, it demonstrates that $N$. labradorica is able to assimilate other inorganic compounds, such as ammonium and sulfate, without light-regulated enzymatic reactions. Albeit not demonstrated, observations suggest that this foraminiferal species might have more than one ammonium and/or sulfate assimilation pathway, involving either the kleptoplasts or unique foraminiferal pathway(s), which remain to be identified (Fig. 8). In any case, electron-opaque bodies, which are often observed in foraminifera (LeKieffre et al., 2018b), seem to play a major role in ammonium and sulfate metabolism compared to other organelles. In addition, fibrillar vesicles might play a role in the transport and storage of sulfated compounds such as glycosaminoglycans.

Finally, while further investigations will be necessary to quantify their uptake and clarify their assimilation pathways, our data provide clear indications that kleptoplastidic benthic foraminifera play a role in sedimentary $\mathrm{N}$ and $\mathrm{S}$ cycles, supporting the suggestion from another benthic foraminifera from aphotic habitats (Grzymski et al., 2002). 


\section{Experimental procedures}

\section{Specimen collection and identification}

Gullmar Fjord (Sweden) sediment samples were collected from a depth of $\sim 70 \mathrm{~m}$ using a boxcorer, (sampling stations: $\sim 58^{\circ} 19^{\prime} 20^{\prime \prime} \mathrm{N} 11^{\circ} 33^{\prime} 10^{\prime \prime} \mathrm{E}$ and $\sim 58^{\circ} 16^{\prime} 40^{\prime \prime} \mathrm{N} 11^{\circ} 29^{\prime} 30^{\prime \prime} \mathrm{E}$ ) in May 2016. At this depth and season, the environment is known to be aphotic (Erlandsson and Stigebrandt, 2006) and oxic (Filipsson and Nordberg, 2004; Groeneveld and Filipsson, 2013). The surface sediment layer $(\sim 0-1 \mathrm{~cm})$ of the box-cores was collected and kept in a container with ambient seawater in darkness during same-day transport to the shore-based laboratory (Sven Lovén Centre for Marine Infrastructure, Kristineberg, University of Gothenburg, Sweden), then carefully sieved over a $300 \mu \mathrm{m}$ mesh using the deep water intake at the marine station. The intake is situated at $32 \mathrm{~m}$ water depth in the fjord. Only the fraction $>300 \mu \mathrm{m}$ was kept, which is the fraction that contains the majority of the targeted species. Nonionellina labradorica appearing healthy (i.e., with brownish green cytoplasm inside the test and an empty last chamber) were carefully and quickly collected with a fine brush using a stereomicroscope under the lowest amount of light possible. The selected specimens were placed overnight in Petri dishes, in darkness, with a small amount of sieved sediment $(63 \mu \mathrm{m})$ and seawater to check for vitality. The next day, specimens showing clear signs of activity (movement and/or reticulopod activity) were collected, carefully cleaned and rinsed several times with in situ seawater (i.e., deep water intake) and then artificial seawater (ASW, Red

Sea Salt, salinity: 34) to minimize bacterial and microalgal contamination. Live foraminifera were then placed in different Petri dishes for isotopic incubation; some specimens were isolated for morphological and DNA analyses. 


\section{Foraminiferal and kleptoplast molecular identification}

Four specimens of $N$. labradorica were selected for DNA analyses, three of them from the sampling campaign of May 2016 (GF366, GF367 and GF379) and another one sampled in May 2014 (GF104) at the same location for comparison. They were air dried for imaging with an environmental scanning electron microscope (SEM, EVO LS10, ZEISS, Oberkochen, Germany) and individually extracted for total DNA in DOC buffer (Pawlowski, 2000; Schweizer et al., 2005) to ensure the taxonomic identification of the foraminifer and origin of kleptoplasts.

To amplify foraminiferal DNA, a hot start $\left(2 \mathrm{~min}\right.$. at $\left.95^{\circ} \mathrm{C}\right) \mathrm{PCR}$ was performed in a volume of $25 \mu \mathrm{l}$ with 40 cycles of $30 \mathrm{~s}$ at $95^{\circ} \mathrm{C}, 30 \mathrm{~s}$ at $50^{\circ} \mathrm{C}$, and $2 \mathrm{~min}$ at $72^{\circ} \mathrm{C}$, followed by $10 \mathrm{~min}$ at $72^{\circ} \mathrm{C}$ for final extension with primers $\mathrm{s} 14 \mathrm{~F} 3$ and $\mathrm{sB}$ for the first PCR and 30 cycles and an annealing temperature of $52^{\circ} \mathrm{C}$ (other parameters unchanged) for the nested PCR with primers s14F1 and J2 (Pawlowski, 2000; Darling et al., 2016).

To amplify non-foraminiferal eukaryotic DNA, two separate amplifications were done through two primer sets, one targeting nuclear rDNA SSU (18S): DiatSSUF-DiatSSUR primers (Pillet et al., 2011) and the other targeting chloroplast rDNA SSU (16S): PLA491FOXY1313R primers (West et al., 2001; Fuller et al., 2006). A hot start (2 min at $\left.95^{\circ} \mathrm{C}\right) \mathrm{PCR}$ was performed in a volume of $25 \mu \mathrm{l}$ with cycles of $30 \mathrm{~s}$ at $95^{\circ} \mathrm{C}, 30 \mathrm{~s}$ at $50^{\circ} \mathrm{C}$, and $2 \mathrm{~min}$ at $72^{\circ} \mathrm{C}$, followed by $10 \mathrm{~min}$ at $72^{\circ} \mathrm{C}$ for final extension. A first trial of amplifications with 40 cycles did not yield any result, so 60 cycles were used for the amplifications of diatom $16 \mathrm{~S}$ and $18 \mathrm{~S}$ rDNA.

Subsequently, positive amplifications with the three different primer sets (only GF104 for foraminiferal DNA and the four selected foraminiferal extractions for $18 \mathrm{~S}$ and $16 \mathrm{~S}$ ) were separately purified with the High Pure PCR Purification Kit (Roche Diagnostics, Meylan, France) and cloned using the pGEM®-T Easy Vector System (Promega, Madison, Wisconsin, 
USA). Clones of foraminiferal (5 clones), 18S (122 clones) and 16S (123 clones) rDNA were sequenced with the Sanger method at GATC Biotech (Cologne, Germany) to get an overview of the diversity found within $N$. labradorica. DNA sequences were then compared with BLAST (Basic Local Alignment Search Tool, blast.ncbi.nlm.nih.gov (Altschul et al., 1997)) for taxonomic identification. In addition, the diatom $18 \mathrm{~S}$ rDNA sequences were placed with a representative selection of diatom sequences taken from GenBank in Seaview v.4 (Gouy et al., 2010), automatically aligned with MUSCLE (Edgar, 2004b, a), implemented in Seaview, and corrected manually. 799 sites out of 839 present in the alignment were selected for the phylogenetic analysis; $61.2 \%$ of these sites had no polymorphism. A molecular phylogenetic tree was built with the PHYML program (Guindon and Gascuel, 2003) and implemented in Seaview, choosing the GTR (General Time Reversible) evolutionary model (Tavaré, 1986) and the approximate Likelihood Ratio Test (aLRT) for branch support estimation (Anisimova and Gascuel, 2006).

\section{Incubation and isotopic labeling}

On the day of the experiment ( $24 \mathrm{~h}$ after sampling), two $3.4 \mathrm{~cm}$ diameter Petri dishes were

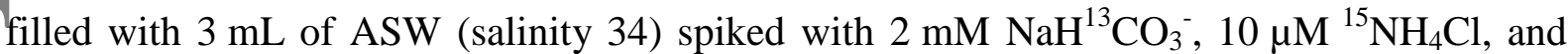
$25 \mathrm{mM} \mathrm{Na}{ }^{34} \mathrm{SO}_{4}$. Five $N$. labradorica were added per Petri dish. Both Petri dishes were placed in a temperature-controlled room $\left(10^{\circ} \mathrm{C}\right)$ for $20 \mathrm{~h}$, one under light (light intensity: $\left.90 \mu \mathrm{mol} \mathrm{m} \mathrm{m}^{-2}\right)$, and the second under dark conditions. At the end of the experiment $(20 \mathrm{~h})$, specimens from each dish were immediately fixed using a solution of $4 \%$ glutaraldehyde with $2 \%$ paraformaldehyde diluted in $0.1 \mathrm{M}$ sodium cacodylate buffer, $0.4 \mathrm{M}$ sucrose and $0.1 \mathrm{M} \mathrm{NaCl}(\mathrm{pH}=7.4)$ for $24 \mathrm{~h}$ at room temperature $\left(\sim 18{ }^{\circ} \mathrm{C}\right)$. These fixed specimens were finally stored at $4{ }^{\circ} \mathrm{C}$ until processing (LeKieffre et al., 2018b). In addition, five specimens 
were fixed at the beginning of the experiment to be used as control for NanoSIMS analysis (see below). These specimens were not placed in spiked ASW.

\section{Electron microscopy (TEM) imaging}

For TEM analysis, the specimens, five for each light condition, were prepared as described in Lekieffre et al. (2018b). Briefly, N. labradorica specimens were rinsed in ASW, decalcified in two successive baths of $0.1 \mathrm{M}$ EDTA (1 and $24 \mathrm{~h}$ ), and post-fixed with $2 \%$ osmium tetroxide for one hour. Foraminifera were then dehydrated with successive ethanol baths and embedded in LR White ${ }^{\circledR}$ resin. Ultrathin sections $(70 \mathrm{~nm})$ were cut using an ultra-microtome (Reichert Ultracut S, Leica, Wetzlar, Germany), placed on finder mesh copper grids, and stained with uranyl acetate (10 min, $2 \%$ aqueous uranyl acetate). The ultrathin sections were finally observed with a Philips 301 CM100 TEM (Philips, Amsterdam, Netherland) at an acceleration voltage of $80 \mathrm{kV}$.

Kleptoplasts were considered healthy when fine structural details were observable, i.e., when the girdle lamellae, thylakoids, and pyrenoids were found intact and well preserved. Kleptoplasts were considered degraded when the structure of the thylakoids and pyrenoid was disrupted, often showing inter-thylakoid spaces and degraded girdle lamellae (Jauffrais et al 2018).

\section{Stable isotope mapping with NanoSIMS and isotopic ratio calculations}

Foraminiferal sections were imaged using a NanoSIMS $50 \mathrm{~L}$ ion microprobe (Cameca,

Gennevilliers, France) to quantify the distribution of ${ }^{13} \mathrm{C},{ }^{15} \mathrm{~N}$ and ${ }^{34} \mathrm{~S}$ enrichment within $N$. labradorica. The areas within the foraminifera analyzed with NanoSIMS were selected from the acquired TEM micrographs. Four specimens were analyzed for dark conditions, and five 
for light conditions. For all specimens, the images were acquired between chambers $n-3$ to $n$ -8 ( $\mathrm{n}$ being most recently formed chamber).

Foraminiferal sections were mounted on $10 \mathrm{~mm}$ disks with double sticking $\mathrm{Cu}$-tape and coated with a $10 \mathrm{~nm}$ gold layer. Subsequently, isotopic images were acquired with the NanoSIMS ion microprobe using 16-keV primary ion beams of $\mathrm{Cs}^{+}$focused to a spot size of about $100 \mathrm{~nm}$. Secondary ions ${ }^{12} \mathrm{C}_{2}^{-},{ }^{13} \mathrm{C}^{12} \mathrm{C}^{-},{ }^{12} \mathrm{C}^{14} \mathrm{~N}^{-},{ }^{12} \mathrm{C}^{15} \mathrm{~N}^{-},{ }^{34} \mathrm{~S}^{-}$, and ${ }^{32} \mathrm{~S}^{-}$were collected simultaneously in electron multipliers. Images were obtained with sizes ranging from $15 \times$ $15 \mu \mathrm{m}$ to $30 \times 30 \mu \mathrm{m}$ at $256 \times 256$ pixels. For each image, 6 layers were acquired, drift corrected, and accumulated using the software L'IMAGE (Dr. Nittler, Carnegie Institution, Washington, USA). The quantified ${ }^{13} \mathrm{C} /{ }^{12} \mathrm{C}$ ratio distribution was obtained from the ratio between ${ }^{12} \mathrm{C}^{13} \mathrm{C}^{-}$and ${ }^{12} \mathrm{C}_{2}^{-}$counts, the ${ }^{15} \mathrm{~N} /{ }^{14} \mathrm{~N}$ ratio distribution was obtained from the ratio between ${ }^{12} \mathrm{C}^{15} \mathrm{~N}^{-}$and ${ }^{12} \mathrm{C}^{14} \mathrm{~N}^{-}$counts, and the ${ }^{34} \mathrm{~S} /{ }^{32} \mathrm{~S}$ ratio distribution was obtained from the ratio between ${ }^{34} \mathrm{~S}^{-}$and ${ }^{32} \mathrm{~S}^{-}$counts. All isotopic enrichments were expressed in the deltanotation, as follows:

$$
\begin{aligned}
& \delta^{13} C(\%)=\left(\left(C_{\text {mes }} / C_{\text {nat }}\right)-1\right) \times 10^{3} \\
& \delta^{15} N(\% 0)=\left(\left(N_{\text {mes }} / N_{\text {nat }}\right)-1\right) \times 10^{3} \\
& \delta^{34} S(\% 0)=\left(\left(S_{\text {mes }} / S_{\text {nat }}\right)-1\right) \times 10^{3}
\end{aligned}
$$

where $X_{m e s}$ is the ratio measured on labeled specimens and $X_{\text {nat }}$ is the average natural ratio measured on unlabeled (control) specimens. Natural variations in ${ }^{13} \mathrm{C},{ }^{15} \mathrm{~N}$ and ${ }^{34} \mathrm{~S}$ enrichments were measured by NanoSIMS in similar areas of unlabelled control $N$.

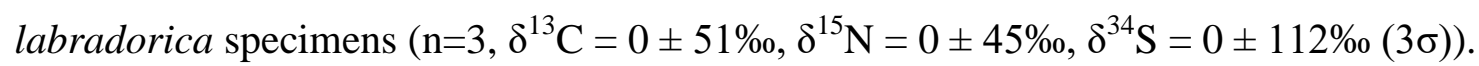




\section{Oxygen measurements and respiration rate calculations}

An oxygen microelectrode $(50 \mu \mathrm{m}$ diameter tip Clark type oxygen electrodes, OXI50 Unisense, Denmark) was used to measure the oxygen flux (Revsbech, 1989) around $N$. labradorica. The microelectrode was calibrated using ASW saturated in oxygen (100\%) and a solution of sodium ascorbate $\left(0.1 \mathrm{M}, 0 \% \mathrm{O}_{2}\right)$. Nonionellina labradorica oxygen respiration rates (pmol $\mathrm{O}_{2}$ cell $^{-1} \mathrm{~d}^{-1}$ ) were then measured as described in Geslin et al. (2011). Briefly, measurements were done in glass micro-tube with an inner diameter of $1 \mathrm{~mm}$. The tube was secured inside a small vial, and filled with ASW (salinity 34). The vial was placed in an aquarium at $10^{\circ} \mathrm{C}$. Five specimens were carefully cleaned and positioned at the bottom of the glass micro-tube. Profiling data acquisition started at a distance of $200 \mu \mathrm{m}$ above the specimens and $\mathrm{O}_{2}$ measurements were taken every $50 \mu \mathrm{m}$ for $5 \mathrm{~s}$ to a distance of $1100 \mu \mathrm{m}$ from the pooled specimens. Data were collected over 2 hour light/ 2 hour dark cycles (300/0 $\mu \mathrm{mol} \mathrm{m} \mathrm{m}^{-2} \mathrm{~s}^{-1}$ ) for a total of 12 to 36 hours and analyzed as previously described (Geslin et al., 2011; Jauffrais et al., 2016).

\section{Images and Data analysis}

The different TEM micrographs were first merged on Photoshop to have a representative surface area of a chamber at magnification $\times 5,800$. Then the total area studied as well as the area and size of kleptoplasts were measured using ImageJ software (Schneider et al., 2012).

All data were expressed as mean \pm standard deviation $(\mathrm{SD})$. Statistical analysis were done using non-parametric analysis (Kruskall-Wallis tests) and differences were considered different at $\mathrm{p}<0.05$.

\section{Acknowledgments}


TJ was funded by the "FRESCO" project, a project supported by the Region Pays de Loire and the University of Angers. This work was also supported by a grant no. 200021_149333 from the Swiss National Science Foundation and the EC2CO/LEFE project "ForChlo" funded by the CNRS. Sophie Quinchard is acknowledged for her technical help in molecular biology.

This work is also a contribution to OM's CRCT project funded by the University of Bordeaux. OM was also supported by a KVA (Royal Swedish Academy of Sciences) grant for Internationalization and Scientific Renewal at the Sven Lovén Centre (SLC) for Marine Sciences. JMB was supported by the Investment in Science Fund at WHOI. The authors thank the Electron Microscopy Facility of the University of Lausanne (Switzerland) where the TEM examination were conducted and Romain Mallet and the SCIAM (Service Commun d'Imagerie et d'Analyses Microscopiques) at the University of Angers (France) for the SEM images. The two anonymous reviewers who greatly improved the manuscript with useful and critical suggestions are also acknowledged.

\section{Competing Interests}

The authors declare that they have no conflict of interest

\section{References}

Altschul, S.F., Madden, T.L., Schäffer, A.A., Zhang, J., Zhang, Z., Miller, W., and Lipman, D.J. (1997) Gapped BLAST and PSI-BLAST: A new generation of protein database search programs. Nucleic Acids Res 25: 3389-3402.

Anisimova, M., and Gascuel, O. (2006) Approximate likelihood-ratio test for branches: A fast, accurate, and powerful alternative. Syst Biol 55: 539-552. 
Aubert, S., Bligny, R., Douce, R., Gout, E., Ratcliffe, R.G., and Roberts, J.K.M. (2001)

Contribution of glutamate dehydrogenase to mitochondrial glutamate metabolism studied by ${ }^{13} \mathrm{C}$ and ${ }^{31} \mathrm{P}$ nuclear magnetic resonance. J Exp Bot 52: 37-45.

Becker, T.W., Nef-Campa, C., Zehnacker, C., and Hirel, B. (1993) Implication of the phytochrome in light regulation of the tomato gene(s) encoding ferredoxin-dependent glutamate synthase. Plant Physiol Biochem 31: 725-729.

Bernhard, J.M. (2003) Potential symbionts in bathyal foraminifera. Science 299: 861.

Bernhard, J.M., and Bowser, S.S. (1999) Benthic foraminifera of dysoxic sediments: chloroplast sequestration and functional morphology. Earth Sci Rev 46: 149-165.

Bernhard, J.M., Habura, A., and Bowser, S.S. (2006) An endobiont-bearing allogromiid from the Santa Barbara Basin: Implications for the early diversification of foraminifera. $J$ Geophys Res Biogeosci 111: 1-10.

Bernhard, J.M., Goldstein, S.T., and Bowser, S.S. (2010) An ectobiont-bearing foraminiferan, Bolivina pacifica, that inhabits microxic pore waters: Cell-biological and paleoceanographic insights. Environ Microbiol 12: 2107-2119.

Bernhard, J.M., Tsuchiya, M., and Nomaki, H. (2018) Ultrastructural observations on prokaryotic associates of benthic foraminifera: Food, mutualistic symbionts, or parasites? Mar Micropaleontol 138: 33-45.

Bernhard, J.M., Buck, K.R., Farmer, M.A., and Bowser, S.S. (2000) The Santa Barbara Basin is a symbiosis oasis. Nature 403: $77-80$.

Bernhard, J.M., Edgcomb, V.P., Casciotti, K.L., McIlvin, M.R., and Beaudoin, D.J. (2012a) Denitrification likely catalyzed by endobionts in an allogromiid foraminifer. ISME J 6: 951960. 
Bernhard, J.M., Casciotti, K.L., McIlvin, M.R., Beaudoin, D.J., Visscher, P.T., and Edgcomb, V.P. (2012b) Potential importance of physiologically diverse benthic foraminifera in sedimentary nitrate storage and respiration. J Geophys Res Biogeosci 117: 1-14.

Bowser, S.S., Alexander, S.P., Stockton, W.L., and Delaca, T.E. (1992) Extracellular-matrix augments mechanical-properties of pseudopodia in the carnivorous foraminiferan Astrammina rara - Role in prey capture. J Protozool 39: 724-732.

Brandsma, J., van de Vossenberg, J., Risgaard-Petersen, N., Schmid, M.C., Engström, P., Eurenius, K., et al. (2011) A multi-proxy study of anaerobic ammonium oxidation in marine sediments of the Gullmar Fjord, Sweden. Envi Microbiol Rep 3: 360-6

Brzezinski, M.A., Olson, R.J., and Chisholm, S.W. (1990) Silicon availability and cell-cycle progression in marine diatoms. Mar Ecol Prog Ser 67: 83-96.

Cedhagen, T. (1988) Position in the sediment and feeding of Astrorhiza limicola Sandahl, 1857 (Foraminiferida). Sarsia 73: 43-47.

Cedhagen, T. (1991) Retention of chloroplasts and bathymetric distribution in the sublittoral foraminiferan Nonionellina labradorica. Ophelia 33: 17-30.

Cedhagen, T. (1994) Taxonomy and biology of Hyrrokkin sarcophaga gen. et sp. n., a parasitic foraminiferan (Rosalinidae). Sarsia 79: 65-82.

Cesbron, F., Geslin, E., Le Kieffre, C., Jauffrais, T., Nardelli, M.P., Langlet, D. et al. (2017) Sequestered chloroplasts in the benthic foraminifer Haynesina germanica: cellular organization, oxygen fluxes and potential ecological implications. J Foraminiferal Res 47: 268-278.

Clark, K.B., Jensen, K.R., and Stirts, H.M. (1990) Survey for functional kleptoplasty among West Atlantic Ascoglossa (=Sacoglossa) (Mollusca: Opisthobranchia). Veliger 33: 339-345.

Correia, M.J., and Lee, J.J. (2000) Chloroplast retention by Elphidium excavatum (Terquem). Is it a selective process? Symbiosis 29: 343-355. 
Correia, M.J., and Lee, J.J. (2002a) How long do the plastids retained by Elphidium excavatum (Terquem) last in their host? Symbiosis 32: 27-37.

Correia, M.J., and Lee, J.J. (2002b) Fine structure of the plastids retained by the foraminifer Elphidium excavatum (Terquem). Symbiosis 32: 15-26.

Darling, K.F., Schweizer, M., Knudsen, K.L., Evans, K.M., Bird, C., Roberts, A. et al. (2016) The genetic diversity, phylogeography and morphology of Elphidiidae (Foraminifera) in the Northeast Atlantic. Mar Micropaleontol 129: 1-23.

Delaca, T.E., Karl, D.M., and Lipps, J.H. (1981) Direct use of dissolved organic-carbon by agglutinated benthic foraminifera. Nature 289: 287-289.

Dupuy, C., Rossignol, L., Geslin, E., and Pascal, P.-Y. (2010) Predation of mudflat meiomacrofaunal metazoans by a calcareous foraminifer, Ammonia tepida (Cushman, 1926). $J$ Foraminiferal Res 40: 305-312.

Edgar, R.C. (2004a) MUSCLE: A multiple sequence alignment method with reduced time and space complexity. BMC Bioinformatics 5: 1-19.

Edgar, R.C. (2004b) MUSCLE: Multiple sequence alignment with high accuracy and high throughput. Nucleic Acids Res 32: 1792-1797.

Erlandsson, C.P., and Stigebrandt, A. (2006) Increased utility of the Secchi disk to assess eutrophication in coastal waters with freshwater run-off. J Mar Syst 60: 19-29.

Ferrario-Méry, S., Suzuki, A., Kunz, C., Valadier, M.H., Roux, Y., Hirel, B., and Foyer, C.H. (2000) Modulation of amino acid metabolism in transformed tobacco plants deficient in FDGOGAT. Plant and Soil 221: 67-79.

Filipsson, H.L., and Nordberg, K. (2004) Climate variations, an overlooked factor influencing the recent marine environment. An example from Gullmar Fjord, Sweden, illustrated by benthic foraminifera and hydrographic data. Estuaries 27: 867-881. 
Finzi-Hart, J.A., Pett-Ridge, J., Weber, P.K., Popa, R., Fallon, S.J., Gunderson, T. et al. (2009) Fixation and fate of $\mathrm{C}$ and $\mathrm{N}$ in the cyanobacterium Trichodesmium using nanometerscale secondary ion mass spectrometry. Proc Natl Acad Sci USA 106: 6345-6350.

Fradkin, S.C. (2001) Rotifer distributions in the coastal waters of the northeast Pacific Ocean. Hydrobiologia 446-447: 173-177.

Fuller, N.J., Tarran, G.A., Cummings, D.G., Woodward, E.M.S., Orcutt, K.M., Yallop, M. et al. (2006) Molecular analysis of photosynthetic picoeukaryote community structure along an Arabian Sea transect. Limnol Oceanogr 51: 2502-2514.

Geslin, E., Risgaard-Petersen, N., Lombard, F., Metzger, E., Langlet, D., and Jorissen, F. (2011) Oxygen respiration rates of benthic foraminifera as measured with oxygen microsensors. J Exp Mar Biol Ecol 396: 108-114.

Goldberg, T., Archer, C., Vance, D., Thamdrup, .B, McAnena, A., Poulton, S.W. (2012) Controls on Mo isotope fractionations in a Mn-rich anoxic marine sediment, Gullmar Fjord, Sweden. Chem Geol 296-297:73-82.

Goldstein, S.T., Bernhard, J.M., and Richardson, E.A. (2004) Chloroplast sequestration in the foraminifer Haynesina germanica: Application of high pressure freezing and freeze substitution. Microsc Microanal 10: 1458-1459.

Goldstein, S.T., Richardson, E.A. (2018) Fine structure of the foraminifer Haynesina germanica (Ehrenberg) and its sequestered chloroplasts. Mar Micropaleontol 138:63-71.

Gouy, M., Guindon, S., and Gascuel, O. (2010) Sea view version 4: A multiplatform graphical user interface for sequence alignment and phylogenetic tree building. Mol Biol Evol 27: $221-224$.

Groeneveld, J., and Filipsson, H.L. (2013) Mg/Ca and Mn/Ca ratios in benthic foraminifera: the potential to reconstruct past variations in temperature and hypoxia in shelf regions. Biogeosciences 10: 5125-5138. 
Grossman, A., and Takahashi, H. (2001) Macronutrient utilization by photosynthetic eukaryotes and the fabric of interactions. Annu Rev Plant Physiol Plant Mol Biol 52: 163-210. Grzymski, J., Schofield, O.M., Falkowski, P.G., and Bernhard, J.M. (2002) The function of plastids in the deep-sea benthic foraminifer, Nonionella stella. Limnol Oceanogr 47: 15691580.

Guindon, S., and Gascuel, O. (2003) A simple, fast, and accurate algorithm to estimate large phylogenies by maximum likelihood. Syst Biol 52: 696-704.

Häusler, R.E., Blackwell, R.D., Lea, P.J., and Leegood, R.C. (1994) Control of photosynthesis in barley leaves with reduced activities of glutamine synthetase or glutamate synthase - I. Plant characteristics and changes in nitrate, ammonium and amino acids. Planta 194: 406-417.

Holzmann, M., and Pawlowski, J. (2017) An updated classification of rotaliid foraminifera based on ribosomal DNA phylogeny. Mar Micropaleontol 132: 18-34.

Hoppe, P., Cohen, S., and Meibom, A. (2013) NanoSIMS: Technical aspects and applications in cosmochemistry and biological geochemistry. Geostand Geoanalytical Res 37: 111-154.

Hoppenrath, M., Beszteri, B., Drebes, G., Halliger, H., Van Beusekom, J.E.E., Janisch, S., and Wiltshire, K.H. (2007) Thalassiosira species (Bacillariophyceae, Thalassiosirales) in the North Sea at Helgoland (German Bight) and Sylt (North Frisian Wadden Sea) - A first approach to assessing diversity. Eur J Phycol 42: 271-288.

Jauffrais, T., Jesus, B., Méléder, V., and Geslin, E. (2017) Functional xanthophyll cycle and pigment content of a kleptoplastic benthic foraminifer: Haynesina germanica. PLOS ONE 12: e0172678.

Jauffrais, T., Jesus, B., Metzger, E., Mouget, J.L., Jorissen, F., and Geslin, E. (2016) Effect of light on photosynthetic efficiency of sequestered chloroplasts in intertidal benthic foraminifera (Haynesina germanica and Ammonia tepida). Biogeosciences 13: 2715-2726. 
Jauffrais, T., LeKieffre, C., Koho, K.A., Tsuchiya, M., Schweizer, M., Bernhard, J.M. et al. (2018) Ultrastructure and distribution of kleptoplasts in benthic foraminifera from shallowwater (photic) habitats. Mar Micropaleontol: 46-62.

Kendall, A.C., Wallsgrove, R.M., Hall, N.P., Turner, J.C., and Lea, P.J. (1986) Carbon and nitrogen metabolism in barley (Hordeum vulgare L.) mutants lacking ferredoxin-dependent glutamate synthase. Planta 168: 316-323.

Kopp, C., Domart-Coulon, I., Escrig, S., Humbel, B.M., Hignette, M., and Meibom, A. (2015a) Subcellular investigation of photosynthesis-driven carbon assimilation in the symbiotic reef coral Pocillopora damicornis. mBio 6: e02299-02214.

Kopp, C., Pernice, M., Domart-Coulon, I., Djediat, C., Spangenberg, J.E., Alexander, D.T.L. et al. (2013) Highly dynamic cellular-level response of symbiotic coral to a sudden increase in environmental nitrogen. mBio 4: e00052-00013.

Kopp, C., Wisztorski, M., Revel, J., Mehiri, M., Dani, V., Capron, L. et al. (2015b) MALDIMS and NanoSIMS imaging techniques to study cnidarian-dinoflagellate symbioses. Zoology 118: $125-131$.

Lam, H.M., Coschigano, K.T., Oliveira, I.C., Melo-Oliveira, R., and Coruzzi, G.M. (1996) The molecular-genetics of nitrogen assimilation into amino acids in higher plants. Annu Rev Plant Physiol Plant Mol Biol 47: 569-593.

Lancien, M., Martin, M., Hsieh, M.H., Leustek, T., Goodman, H., and Coruzzi, G.M. (2002) Arabidopsis glt1-T mutant defines a role for NADH-GOGAT in the non-photorespiratory ammonium assimilatory pathway. Plant J 29: 347-358.

Langer, M.R. (1992) Biosynthesis of glycosaminoglycans in foraminifera: A review. Mar Micropaleontol 19: 245-255.

Lee, J.J., Lanners, E., and Ter Kuile, B. (1988) The retention of chloroplasts by the foraminifera Elphidium crispum. Symbiosis 5: 45-60. 
Lekieffre, C., Jauffrais, T., Geslin, E., Jesus, B., Bernhard, J.M., Giovani, M.E., et al. (2018a) Inorganic carbon and nitrogen assimilation in cellular compartments of a benthic kleptoplastic foraminifer. Sci Rep 8, Article number: 10140

LeKieffre, C., Spangenberg, J.E., Mabilleau, G., Escrig, S., Meibom, A., and Geslin, E. (2017) Surviving anoxia in marine sediments: The metabolic response of ubiquitous benthic foraminifera (Ammonia tepida). PLOS ONE 12: e0177604.

LeKieffre, C., Bernhard, J.M., Mabilleau, G., Filipsson, H.L., Meibom, A., and Geslin, E. (2018b) An overview of cellular ultrastructure in benthic foraminifera: New observations of rotalid species in the context of existing literature. Mar Micropal 138: 12-32.

Leustek, T., and Saito, K. (1999) Sulfate transport and assimilation in plants. Plant Physiol 120: $637-643$.

Lopez, E. (1979) Algal chloroplasts in the protoplasm of three species of benthic foraminifera: taxonomic affinity, viability and persistence. Mar Biol 53: 201-211.

Lunn, J.E., Droux, M., Martin, J., and Douce, R. (1990) Localization of ATP sulfurylase and O-acetylserine(thiol)lyase in spinach leaves. Plant Physiol 94: 1345-1352.

Magalhães, J.R., Ju, G.C., Rich, P.J., and Rhodes, D. (1990) Kinetics of ${ }^{15} \mathrm{NH}^{4+}$ assimilation in Zea mays: Preliminary studies with a glutamate dehydrogenase (GDH1) null mutant. Plant Physiol 94: 647-656.

McQuoid, M.R. (2005) Influence of salinity on seasonal germination of resting stages and composition of microplankton on the Swedish west coast. Mar Ecol Prog Ser 289: 151-163.

Melo-Oliveira, R., Oliveira, I.C., and Coruzzi, G.M. (1996) Arabidopsis mutant analysis and gene regulation define a nonredundant role for glutamate dehydrogenase in nitrogen assimilation. Proc Natl Acad Sci USA 93: 4718-4723.

Miyagishima, S. (2011) Mechanism of plastid division: From a bacterium to an organelle. Plant Physiol 155: 1533-1544. 
Moodley, L., Middelburg, J.J., Boschker, H.T.S., Duineveld, G.C.A., Pel, R., Herman, P.M.J., and Heip, C.H.R. (2002) Bacteria and Foraminifera: key players in a short-term deep-sea benthic response to phytodetritus. Mar Ecol Prog Ser 236: 23-29.

Musat, N., Stryhanyuk, H., Bombach, P., Adrian, L, Audinot, J.N., Richnow, H.H. (2014).

The effect of FISH and CARD-FISH on the isotopic composition of 13C- and 15N-labeled Pseudomonas putida cells measured by nanoSIMS. Syst Appl Microbio. 37: 267-76.

Nomaki, H., Ogawa, N.O., Ohkouchi, N., Suga, H., Toyofuku, T., Shimanaga, M. et al. (2008) Benthic foraminifera as trophic links between phytodetritus and benthic metazoans: carbon and nitrogen isotopic evidence. Mar Ecol Prog Ser 357: 153-164.

Nomaki, H., Bernhard, J.M., Ishida, A., Tsuchiya, M., Uematsu, K., Tame, A. et al. (2016) Intracellular isotope localization in Ammonia sp. (Foraminifera) of oxygen-depleted environments: Results of nitrate and sulfate labeling experiments. Frontiers Microbiol 7: 112.

Nuñez, J., Renslow, R., Cliff, J.B., and Anderton, C.R. (2018) NanoSIMS for biological applications: Current practices and analyses. Biointerphases 13: $03 \mathrm{~b} 301$.

Oliveira, I.C., and Coruzzi, G.M. (1999) Carbon and amino acids reciprocally modulate the expression of glutamine synthetase in Arabidopsis. Plant Physiol 121: 301-309.

Pawlowski, J. (2000) Introduction to the molecular systematics of foraminifera. Micropaleontol 46: 1-12.

Pawlowski, J., \& Holzmann, M. (2014). A plea for DNA barcoding of foraminifera. The $J$ Foraminiferal Res 44: 62-67.

Pernice, M., Meibom, A., Van Den Heuvel, A., Kopp, C., Domart-Coulon, I., HoeghGuldberg, O., and Dove, S. (2012) A single-cell view of ammonium assimilation in coraldinoflagellate symbiosis. ISME J 6: 1314-1324. 
Pillet, L., de Vargas, C., and Pawlowski, J. (2011) Molecular identification of sequestered diatom chloroplasts and kleptoplastidy in foraminifera. Protist 162: 394-404.

Piña-Ochoa, E., Koho, K.A., Geslin, E., and Risgaard-Petersen, N. (2010a) Survival and life strategy of the foraminiferan Globobulimina turgida through nitrate storage and denitrification. Mar Ecol Prog Ser 417: 39-49.

Piña-Ochoa, E., Hogslund, S., Geslin, E., Cedhagen, T., Revsbech, N.P., Nielsen, L.P. et al. (2010b) Widespread occurrence of nitrate storage and denitrification among foraminifera and gromiida. Proc Natl Acad Sci USA 107: 1148-1153.

Raina, J.B., Clode, P.L., Cheong, S., Bougoure, J., Kilburn, M.R., Reeder, A. et al. (2017) Subcellular tracking reveals the location of dimethylsulfoniopropionate in microalgae and visualises its uptake by marine bacteria. eLife $\mathbf{6}$.

Revsbech, N.P. (1989) An oxygen microsensor with a guard cathode. Limnol Oceanogr 34: $474-478$.

Rink, S., Kuhl, M., Bijma, J., and Spero, H.J. (1998) Microsensor studies of photosynthesis and respiration in the symbiotic foraminifer Orbulina universa. Mar Biol 131: 583-595.

Risgaard-Petersen, N., Langezaal, A.M., Ingvardsen, S., Schmid, M.C., Jetten, M.S.M., Op den Camp, H.J.M. et al. (2006) Evidence for complete denitrification in a benthic foraminifer. Nature 443: 93-96.

Saito, K. (2000) Regulation of sulfate transport and synthesis of sulfur-containing amino acids. Curr Opin Plant Biol 3: 188-195.

Sakakibara, H., Kawabata, S., Hase, T., and Sugiyama, T. (1992) Differential effects of nitrate and light on the expression of glutamine synthetases and ferredoxin-dependent glutamate synthase in maize. Plant Cell Physiol 33: 1193-1198. 
Schmidt C, Titelboim D, Brandt J, Herut B, Abramovich S, Almogi-Labin A, et al. (2016) Extremely heat tolerant photo-symbiosis in a shallow marine benthic foraminifera. Sci Rep 6: Article number:630930.

Schweizer, M., Pawlowski, J., Kouwenhoven, T., and Van Der Zwaan, B. (2009) Molecular phylogeny of common cibicidids and related rotaliida (foraminifera) based on small subunit rDNA sequences. J Foraminiferal Res 39: 300-315.

Schweizer, M., Pawlowski, J., Duijnstee, I.A.P., Kouwenhoven, T.J., and Van Der Zwaan, G.J. (2005) Molecular phylogeny of the foraminiferal genus Uvigerina based on ribosomal DNA sequences. Mar Micropaleontol 57: 51-67.

Schweizer, M., Pawlowski, J., Kouwenhoven, T.J., Guiard, J., and van der Zwaan, B. (2008) Molecular phylogeny of Rotaliida (Foraminifera) based on complete small subunit rDNA sequences. Mar Micropaleontol 66: 233-246.

Somerville, C.R., and Ogren, W.L. (1980) Inhibition of photosynthesis in Arabidopsis mutants lacking leaf glutamate synthase activity. Nature 286: 257-259.

Sumiya, N., Fujiwara, T., Era, A., and Miyagishima, S.-y. (2016) Chloroplast division checkpoint in eukaryotic algae. PNAS 113: E7629-E7638.

Suzuki, A., and Knaff, D.B. (2005) Glutamate synthase: Structural, mechanistic and regulatory properties, and role in the amino acid metabolism. Photosynth Res 83: 191-217.

Tavaré, S. (1986) Some probabilistic and statistical problems in the analysis of DNA sequences. In Lectures on Mathematics in the Life Sciences. Miura, R.M. (ed). Providence: Am. Math. Soc., pp. 57-86.

Teugels, B., Bouillon, S., Veuger, B., Middelburg, J.J., and Koedam, N. (2008) Kleptoplasts mediate nitrogen acquisition in the sea slug Elysia viridis. Aquatic Biol 4: 15-21. 
Tsuchiya, M., Toyofuku, T., Uematsu, K., Brüchert, V., Collen, J., Yamamoto, H., and Kitazato, H. (2015) Cytologic and genetic characteristics of endobiotic bacteria and kleptoplasts of Virgulinella fragilis (Foraminifera). J Euk Microbiol 62: 454-469.

Tsuchiya, M., Chikaraishi, Y., Nomaki, H., Sasaki, Y., Tame, A., Uematsu, K., et al. (2018)

Compound-specific isotope analysis of benthic foraminifer amino acids suggests microhabitat variability in rocky-shore environments. Ecol Evol. in press. https://doi.org/10.1002/ece3.4358

Vaulot, D., Olson, R.J., Merkel, S., and Chisholm, S.W. (1987) Cell-cycle response to nutrient starvation in two phytoplankton species, Thalassiosira weissflogii and Hymenomonas carterae. Mar Biol 95: 625-630.

West, N.J., Schönhuber, W.A., Fuller, N.J., Amann, R.I., Rippka, R., Post, A.F., and Scanlan, D.J. (2001) Closely related Prochlorococcus genotypes show remarkably different depth distributions in two oceanic regions as revealed by in situ hybridization using 16S rRNAtargeted oligonucleotides. Microbiol 147: 1731-1744.

Witte, U., Wenzhöfer, F., Sommer, S., Boetius, A., Heinz, P., Aberle, N. et al. (2003) In situ experimental evidence of the fate of a phytodetritus pulse at the abyssal sea floor. Nature $\mathbf{4 2 4}$ : 763-766. 
Figure 1. SEM images and pie charts showing the different percentages of $18 \mathrm{~S}$ and $16 \mathrm{~S}$ clones for each sequenced specimen of $N$. labradorica. Scale bars: $50 \mu \mathrm{m}$.

Figure 2. Partial 18S rDNA phylogeny of Thalassiosirales inferred using the ML method with the GTR model and the aLRT SH-like branch support. Sequences from this study are indicated in bold.

Figure 3. Electron microscopic micrographs of Nonionellina labradorica. A. SEM micrograph of a typical test (shell). B. Low magnification view of the cytoplasm showing numerous lipid droplets and chloroplasts. C and D. Intact (c) and degraded (c*) chloroplasts. The intact chloroplasts exhibit undamaged pyrenoid and thylakoids, while the degraded chloroplasts were in degradation vacuoles or had peripheral degradation of the membranes (inset: degradation vesicles of the chloroplast observed in D). E and F. Higher magnification view of an electron-opaque bodies and lipid (in E). G. High-magnification image of fibrillar vesicles with clearly distinguishable fibrils adjacent to an intact mitochondrion. c: intact chloroplast, $\mathrm{c}^{*}$ : degraded chloroplast, dc: double chloroplast, eo: electron-opaque bodies, fv: fibrillar vesicles, li: lipid droplets; m: mitochondria, v: vacuole. Scale bars: A = 100 $\mu \mathrm{m}, \mathrm{B}=5$ $\mu \mathrm{m} ; \mathrm{C}, \mathrm{D}=2 \mu \mathrm{m} ; \mathrm{E}=1 \mu \mathrm{m} ; \mathrm{F}, \mathrm{G}=500 \mathrm{~nm}$.

Figure 4. TEM micrographs of the cytoplasm of Nonionellina labradorica incubated $20 \mathrm{~h}$ in dark (A and C) or light (B and D). A, C. After dark incubation, the cytoplasm exhibited intact chloroplasts with undamaged pyrenoids and thylakoids, but also some degrading chloroplasts. A few double chloroplasts were present. The numerous lipid droplets and the mitochondria (see text) were intact. All structures have well preserved membranes. B, D. 
After light incubation, the only recognizable organelles were chloroplasts and lipid droplets; the rest of the cytoplasm was degraded and had a patchy aspect, thus the foraminiferal chambers looked empty. Vacuoles were lysed and the rest of the cytoplasm was condensed into patchy dense areas. All chloroplasts were degrading and some of the lipid droplets were in lysis, with electron lucent inclusions (arrowheads). c: intact chloroplast, $\mathrm{c}^{*}$ : degrading chloroplast, dc: double chloroplast, li: lipid droplets; li*: lipid droplets in lysis, v: vacuole. Scale bars: $2 \mu \mathrm{m}$.

Figure 5. TEM and NanoSIMS micrographs from $N$. labradorica incubated in darkness. ${ }^{13} \mathrm{C}$ and ${ }^{15} \mathrm{~N}$ cellular localization in the cytoplasm of $N$. labradorica after $20 \mathrm{~h}$ of incubation in dark with $\mathrm{H}^{13} \mathrm{CO}_{3}{ }^{-}(\mathbf{A}, \mathbf{B}, \mathbf{C}),{ }^{15} \mathrm{NH}_{4}{ }^{+}(\mathbf{D}, \mathbf{E}, \mathbf{F})$ and ${ }^{34} \mathrm{SO}_{4}{ }^{2-}(\mathbf{G}, \mathbf{H}, \mathbf{I})$. Left column: TEM micrographs; central column: overlay of the TEM and NanoSIMS images; right column: corresponding NanoSIMS $\delta^{13} \mathrm{C}, \delta^{15} \mathrm{~N}$ and $\delta^{34} \mathrm{~S}$ images (with scales expressed in \%o). Arrows: fibrillar vesicles; arrowheads: electron opaque bodies; stars: unidentified labeled organelles; c: intact chloroplast; $\mathrm{c}^{*}$ : chloroplast in degradation; li: lipid droplets. Scale bars: $2 \mu \mathrm{m}$.

Figure 6. TEM and NanoSIMS micrographs from $N$. labradorica incubated in light: ${ }^{13} \mathrm{C}$ and ${ }^{15} \mathrm{~N}$ cellular localization in the cytoplasm of $N$. labradorica after $20 \mathrm{~h}$ of incubation in light with $\mathrm{H}^{13} \mathrm{CO}_{3}{ }^{-}(\mathbf{A}, \mathbf{B}, \mathbf{C}),{ }^{15} \mathrm{NH}_{4}{ }^{+}(\mathbf{D}, \mathbf{E}, \mathbf{F})$ and ${ }^{34} \mathrm{SO}_{4}{ }^{2-}(\mathbf{G}, \mathbf{H}, \mathbf{I})$. Left column: TEM micrographs; central column: overlay of the TEM and NanoSIMS images; right column: corresponding NanoSIMS $\delta^{13} \mathrm{C}, \delta^{15} \mathrm{~N}$ and $\delta^{34} \mathrm{~S}$ images (with scales expressed in \%o). Arrows: fibrillar vesicles; arrowheads: electron opaque bodies; stars: unidentified labeled organelles; c: intact chloroplast; $\mathrm{c}^{*}$ : chloroplast in degradation; li: lipid droplets; li*: lipid droplets in lysis. Scale bars: $2 \mu \mathrm{m}$. 
Figure 7. Respiration rates of a pool of five N. labradorica $\left(\mathrm{pmol} \mathrm{O}_{2}\right.$ cell $^{-1}$ day $\left.^{-1}\right)$ over 36 hours of a $2 \mathrm{~h}$ light/ $2 \mathrm{~h}$ dark cycle.

Figure 8. Schematic hypothetical inorganic $\mathrm{C}, \mathrm{N}$ and $\mathrm{S}$ assimilation processes in $N$. labradorica from an aphotic habitat. A. In this scenario, $\mathrm{N}$ metabolism is functional while $\mathrm{C}$ metabolism is not. Different possible enzymatic pathways are placed in either the kleptoplast, mitochondrion or foraminiferal cytoplasm. B. Possible S-assimilation pathways in N. labradorica. PS, Photosystem (I or II); ETR, electron transport chain; GS, glutamine synthetases; GOGAT, glutamine 2 oxoglutarate aminotransferase; AA, Amino acids; APS, adenosine 5'-phosphosulphate; SIR, Sulfite reductase; OASTL, O-acetylserine(thiol)lyase. Note that these scenarios cannot be transferred to all kleptoplastidic foraminiferal species as many have access to light.

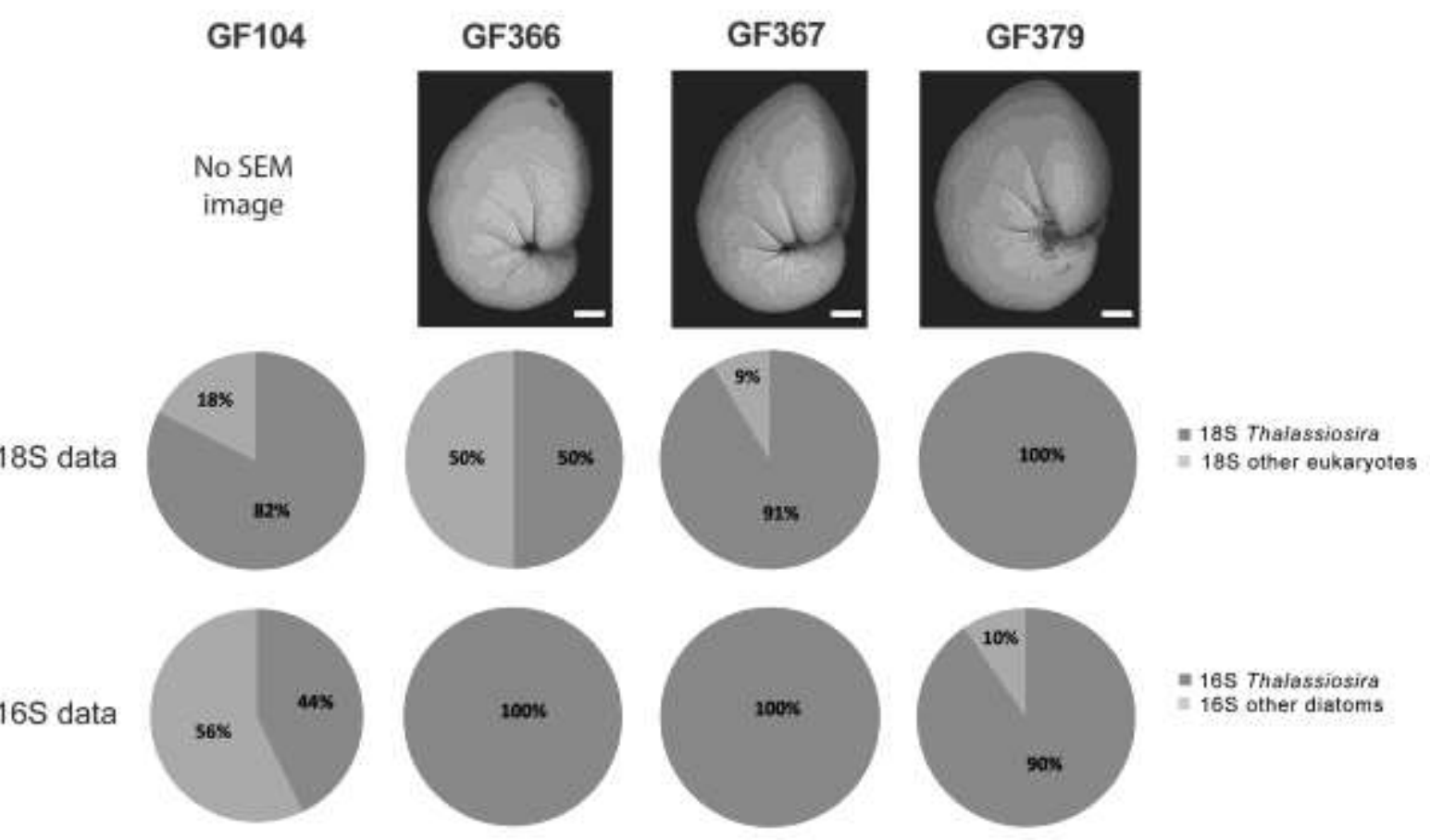



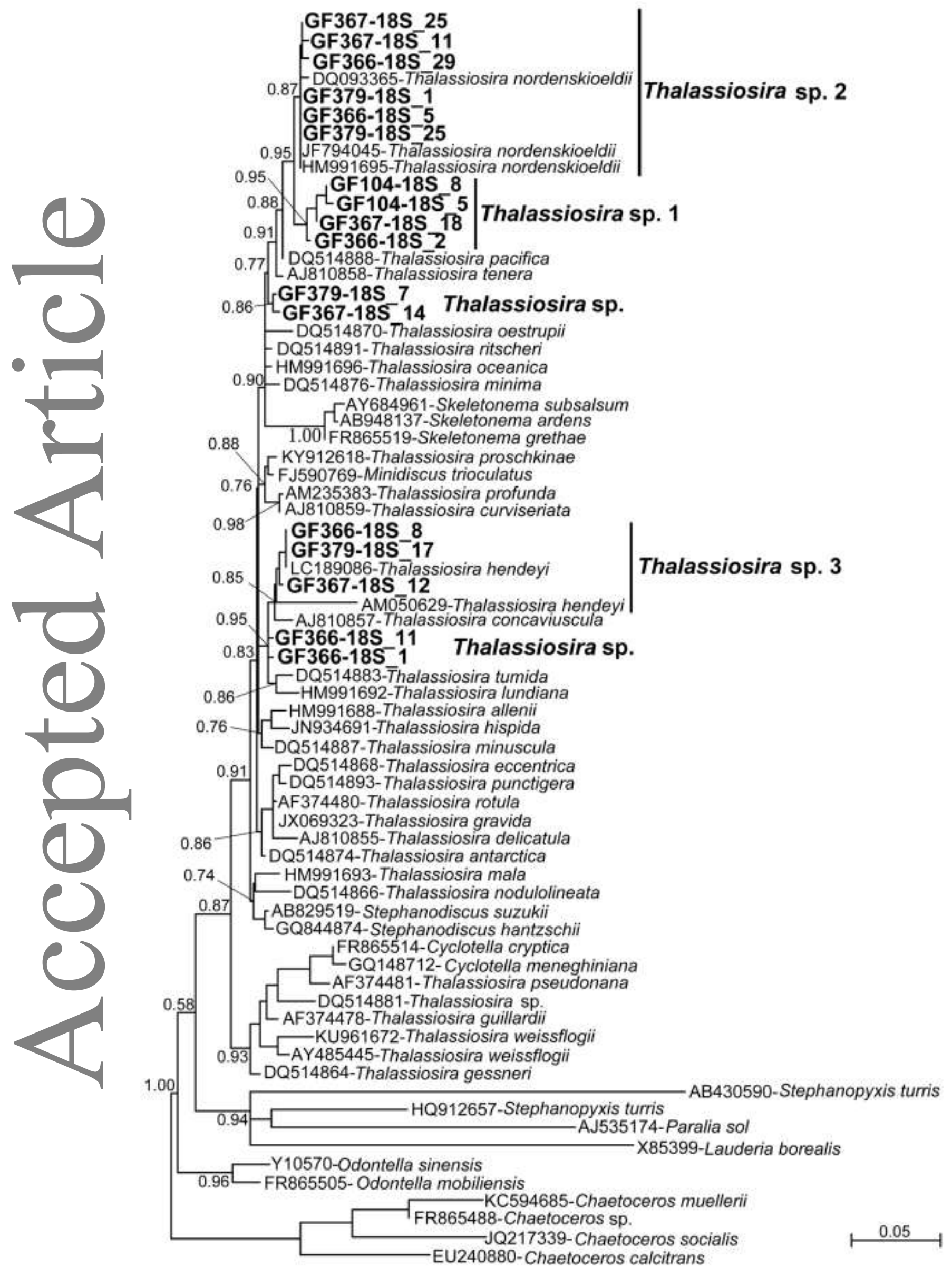

This article is protected by copyright. All rights reserved. 


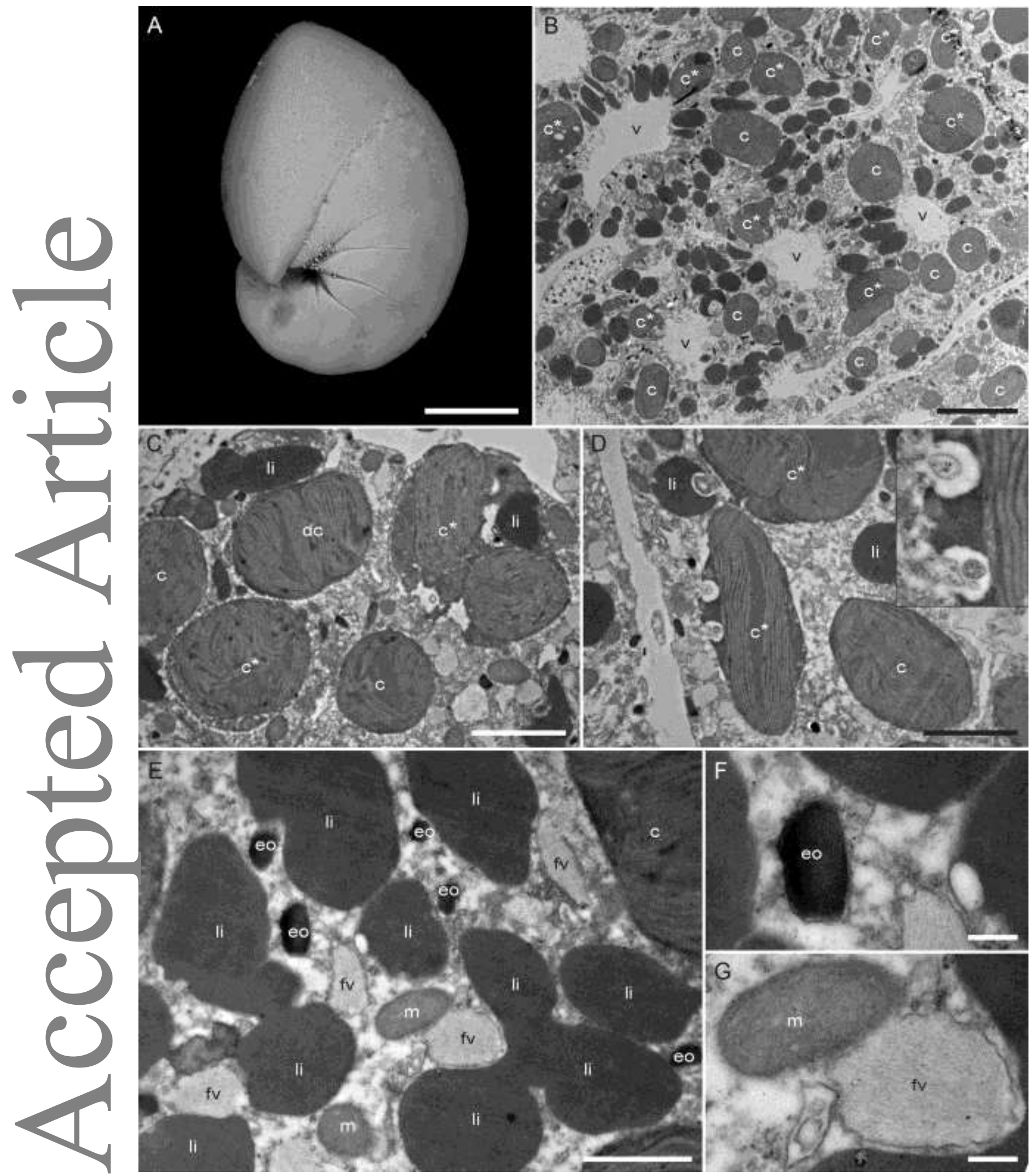

This article is protected by copyright. All rights reserved. 


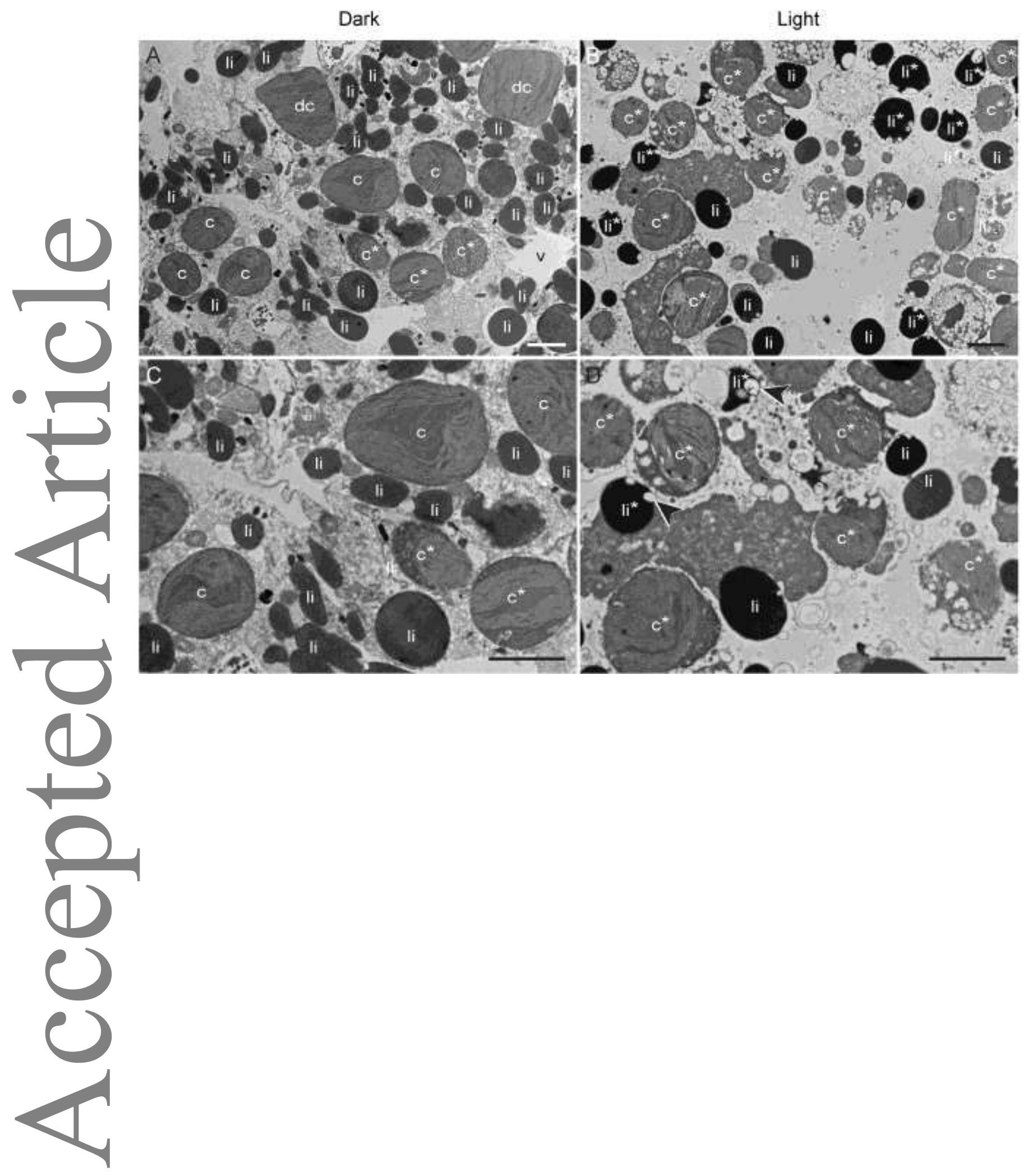

This article is protected by copyright. All rights reserved. 


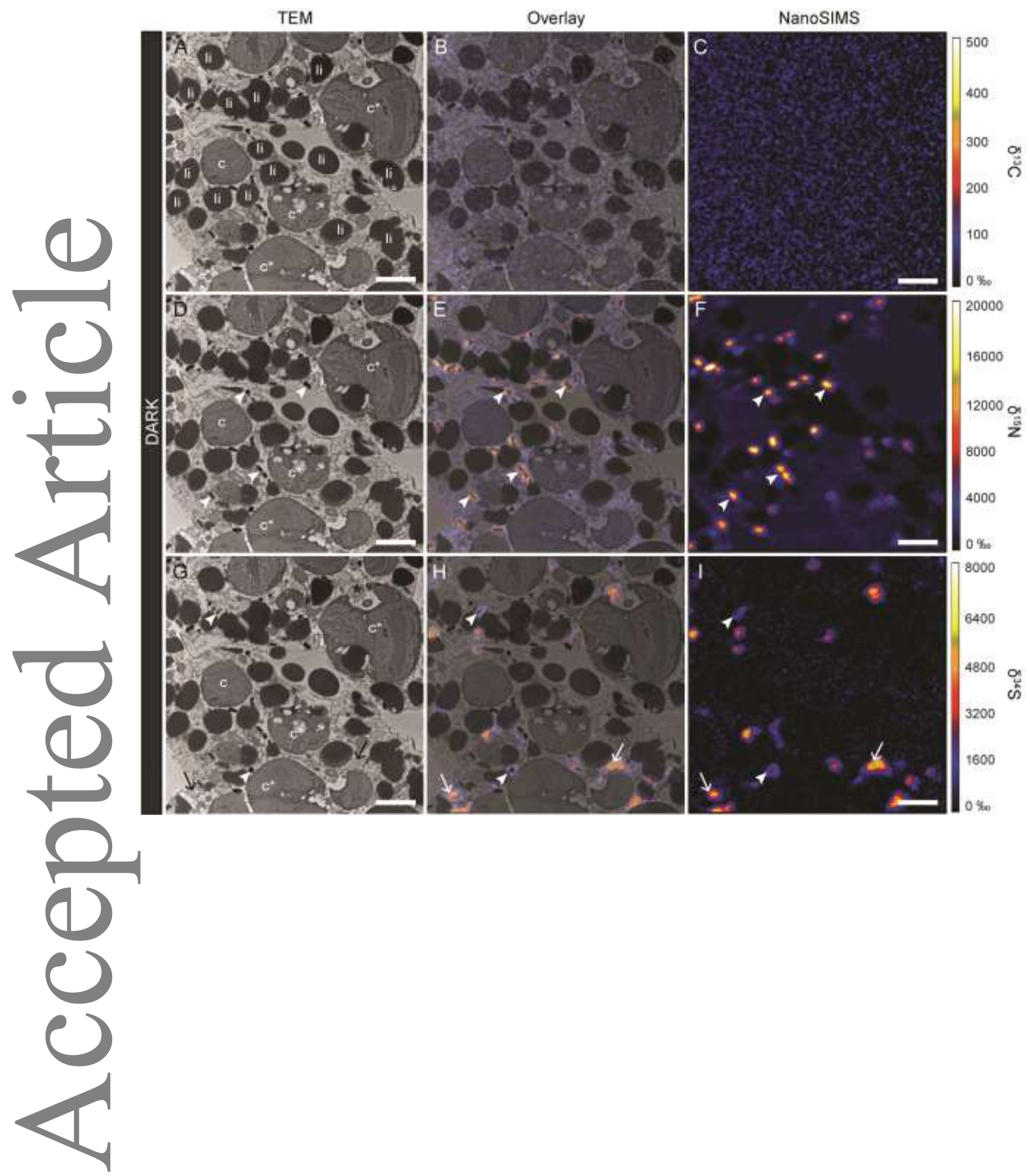

This article is protected by copyright. All rights reserved. 


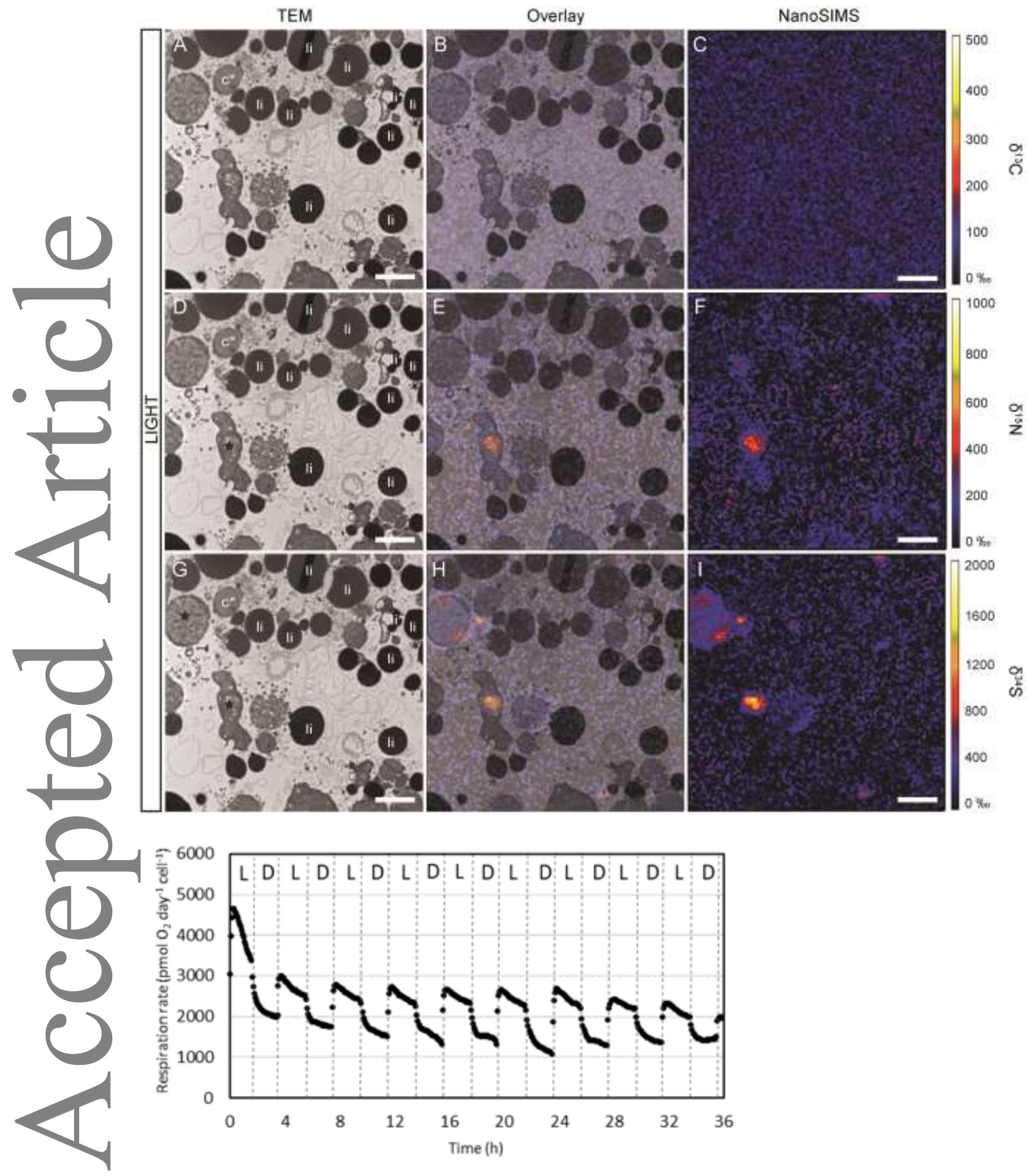




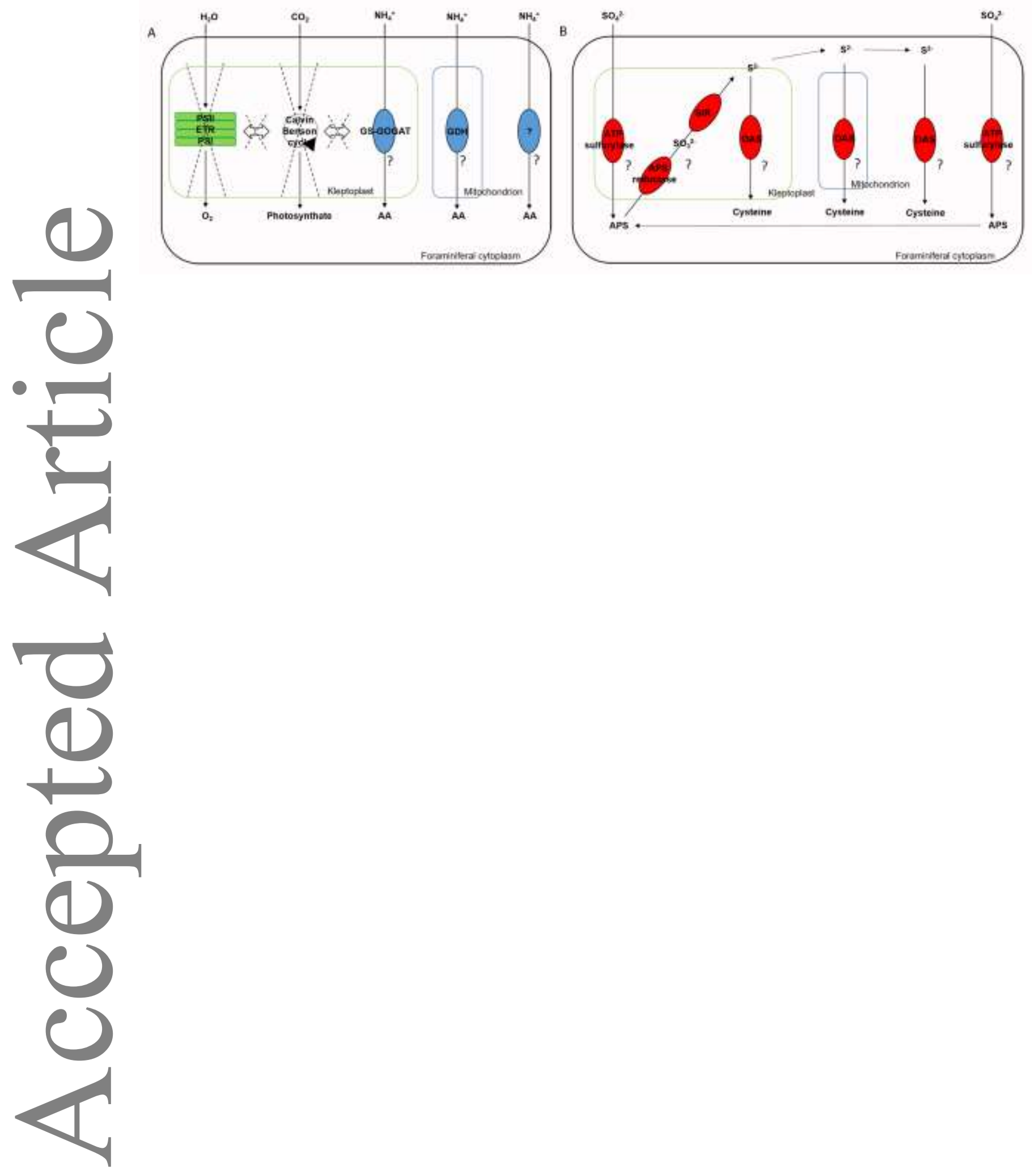

This article is protected by copyright. All rights reserved. 